\title{
Post-print
}

Submitted, accepted and published in Applied Catalysis A: General, 2018 (559) 10-19 https://doi.org/10.1016/j.apcata.2018.04.011

\section{Screening of Ni-Cu bimetallic catalysts for hydrogen and carbon nanofilaments production via catalytic decomposition of methane}

\author{
D. Torres, J.L. Pinilla*, I. Suelves \\ Instituto de Carboquímica, ICB-CSIC, Miguel Luesma Castán, 4, 50018 Zaragoza, Spain
}

\begin{abstract}
The catalytic decomposition of methane (CDM) is a $\mathrm{H}_{2}$ production process in which the $\mathrm{CO}_{2}$ emission of conventional processes is avoided and from which carbon nanofilaments can be obtained as a high added value by-product. In this work, we present a thermogravimetry-based screening of catalysts according to their carbon production in the CDM reaction. Catalysts studied were based on Ni as active phase, using two textural promoters $\left(\mathrm{Al}_{2} \mathrm{O}_{3}\right.$ or $\left.\mathrm{MgO}\right)$ and $\mathrm{Cu}$ as dopant element in different proportions: 2.5, 5.0, 7.5 and $10 \mathrm{~mol} \% . \mathrm{Cu}$ doping resulted in an increase in both the maximum temperature of activity $\left(>100^{\circ} \mathrm{C}\right.$ ) and the carbon formation rate, which were maximum for a Cu content of $7.5 \mathrm{~mol}$ $\%$, regardless of the textural promoter used. The formation of a solid solution of $\mathrm{Ni}_{(x)} \mathrm{Cu}(1-x)$, with lattice constants and particle size distribution highly dependent on the Cu content, led to the formation of fishbone carbon nanofibers with different morphological features, such as the $\alpha$ angle between the graphene stacks and the growth axis of the nanofilament, the diameter, the length and the formation or not of an inner hollow.
\end{abstract}

\footnotetext{
*Corresponding author: e-mail address: jlpinilla@icb.csic.es (José Luis Pinilla))
} 
Keywords: $\mathrm{Ni}-\mathrm{Cu}$ catalysts, bimetallic catalysts, hydrogen, catalytic decomposition of methane, thermogravimetric analysis. 


\section{INTRODUCTION}

The catalytic decomposition of methane $(\mathrm{CDM})$ is a $\mathrm{H}_{2}$ production process in which the $\mathrm{CO}_{2}$ emission of conventional processes is avoided and from which nanostructured carbon can be obtained as a high added value by-product [1]. The thermal methane decomposition reaction is moderately endothermic $\left(\mathrm{CH}_{4}(\mathrm{~g}) \rightarrow \mathrm{C}(\mathrm{s})+2 \mathrm{H}_{2}(\mathrm{~g}), \Delta H_{0}=75.6 \mathrm{~kJ} \mathrm{~mol}^{-1}\right)$, requiring high temperature $\left(>1200^{\circ} \mathrm{C}\right)$ to achieve the non-catalytic methane dissociation with a reasonable conversion $[2,3]$. Amorphous forms of carbon such as carbon black are obtained in that case. These temperatures can be moderated by using metal catalysts based on transition metals such as $\mathrm{Ni}$, $\mathrm{Co}$ or $\mathrm{Fe}$, which present partially filled $3 \mathrm{~d}$ orbitals improving the dissociation of $\mathrm{CH}_{4}$ molecules through partially accepting electrons [4]. Likewise, this has been shown to be effective in the formation of carbon nanofilaments in the CDM reaction due to the high solubility and diffusion capacity of the carbon atoms through them [3-5]. Among the transition metals mentioned, Ni-based catalysts are most wide studied due to the higher catalytic activity in the $\mathrm{CDM}$ reaction $(\mathrm{Ni}>\mathrm{Co}>\mathrm{Fe}[4,6])$ resulting from the greatest decrease in the dissociation energy of $\mathrm{C}-\mathrm{H}$ bonds, in addition to a known ability to produce carbon nanofilaments such as nanofibers $(\mathrm{CNF})$ or carbon nanotubes $(\mathrm{CNT})[2,7]$.

According to the $\mathrm{CDM}$ reaction, $\mathrm{CH}_{4}$ conversion increases as the reaction temperature does; however, Ni catalysts efficiency is limited by its deactivation at high temperature, which prevents the achievement of relatively high methane conversion due to thermodynamic limitations. Therefore, the addition of an appropriate dopant is necessary in order to permit higher reaction temperatures and hence improve the methane conversion, assuring simultaneously a long catalyst lifetime by the formation of nanofilamentous carbon. Besides this, the possibility of operating at higher temperatures improves the graphitic order of the nanofilaments obtained by CDM, what could be interesting in the carbonaceous product valorization and affect the economy of the $\mathrm{H}_{2}$ production process [2]. In this regard, 
bimetallic catalysts based on the doping with low contents of noble ( $\mathrm{Ni}-\mathrm{Cu}, \mathrm{Ni}-\mathrm{Pt}, \mathrm{Ni}-\mathrm{Pd}$ ), ferrous (Ni-Co, $\mathrm{Ni}-\mathrm{Fe})$ and refractory metals $(\mathrm{Ni}-\mathrm{Mo})$ were explored [8-16]. Among them, $\mathrm{Cu}$ doping involving the formation of the $\mathrm{Ni}_{(\mathrm{x})} \mathrm{Cu}_{(1-\mathrm{x})}$ alloy stands out for enhancing the catalyst stability and activity at high temperature in addition to improving its reducibility and modifying the crystalline structure of the resulting carbon nanofilaments [17-31].

$\mathrm{Ni}$ dispersion and sintering related challenges have also been addressed playing with the catalytic support [31-33] or the preparation method, which influence the formation of Nibased alloys when a dopant is involved in the catalyst preparation. Conventional supports for $\mathrm{Ni}$ supported catalysts include metal oxides $\left(\mathrm{SiO}_{2}, \mathrm{Al}_{2} \mathrm{O}_{3}, \mathrm{TiO}_{2}, \mathrm{MgO}\right.$, and $\left.\mathrm{ZrO}_{2}\right)[29,34,35]$, carbon materials $[25,27,35]$ or zeolites and mesoporous silica [28, 31, 36] among the most used due to their thermal and chemical stability. A suitable support improves the CDM reaction influencing in the Ni crystal size and its dispersion, the support/metal interaction and the carbon diffusion mechanism [37-39]. The support particle size and textural configuration also influenced the $\mathrm{Ni}_{(\mathrm{x})} \mathrm{Cu}_{(1-\mathrm{x})}$ alloy dispersion [28, 31]. As for the reported $\mathrm{Ni}_{(\mathrm{x})} \mathrm{Cu}_{(1-\mathrm{x})}$ alloy catalysts preparation methods (sol-gel, impregnation, co-precipitation and fusion) $[4,18,21$ $23,30,40,41]$, these showed in most cases a heterogeneous particle dispersion and a low metal size control. A previous comparison of the co-precipitation, impregnation and fusion methods for obtaining catalysts of $\mathrm{Ni}$ and $\mathrm{Ni}_{(\mathrm{x})} \mathrm{Cu}_{(1-\mathrm{x})}$ alloy for the $\mathrm{CDM}$ reaction showed that the preparation method has no influence in the crystalline structure of the resulting carbon nanofilaments [22]. In any case, the cause of the inhomogeneity observed in diameter and structure of the nanofilaments as well as the relationship between the catalytic activity and the properties of the $\mathrm{Ni}_{(\mathrm{x})} \mathrm{Cu}_{(1-\mathrm{x})}$ alloy which is formed are still unclear [24].

Regarding the formation of a particular filamentous structure, there are many essential variables such as the catalyst, including size, composition and crystalline structure of the active metal nanoparticles, as well as the support properties, the operating temperature and 
pressure, or the gas feedstock composition, among the most outstanding [4, 42]. Nevertheless, although the carbon structure directly depends on the catalytic metal and the metal-graphite interface, the formation of successive graphene layers takes place on specific faces or planes of the metallic nanoparticle. In the case of $\mathrm{Ni}$, the planes (100) and (110) serve as the gasmetal interface while the surfaces (111) and (311) are in contact with the growing graphite planes $(002)[17,43]$. Moreover, the formation of alloys, what occurs with some bimetallic catalysts when parent metals present similar crystallographic properties, also affects the interfaces discussed above with the modification of the original Ni crystalline structure (e.g. lattice constant in the face-centered cubic system of $\mathrm{Ni}$ ). In case of $\mathrm{Cu}$ as dopant, it enhances the methane chemisorption on clean $\mathrm{Ni}$ surfaces and/or facilitates nanofilament growth through the dilution effect derived from Ni alloying [19].

The novelty of this work lies in the comparative evaluation of $\mathrm{Ni}$ - and $\mathrm{Ni}-\mathrm{Cu}$-based catalysts in the CDM reaction, studying the combined influence of the composition of the catalyst, including different doping percentage and textural promoter, and the operating conditions used, including mode, temperature and scale, in its yield to high added-value carbon nanofilaments and the resulting final textural and structural properties. Therefore, the main objective is to develop $\mathrm{Ni} / \mathrm{MgO}$ and $\mathrm{Ni} / \mathrm{Al}_{2} \mathrm{O}_{3}$ catalysts and study the effect of $\mathrm{Cu}$ doping (loadings between 2.5 and 10.0 mol. \%) on the $\mathrm{Ni}_{(\mathrm{x})} \mathrm{Cu}_{(1-\mathrm{x})}$ alloy formation and their subsequent catalytic stability and activity in the CDM. The screening method used here is based on TGA whose effectiveness in the fast evaluation of catalysts in the CDM reaction has already been proven [44-46]. Hydrogen and carbon formation was evaluated firstly in a thermobalance in isothermal and temperature programmed modes, and subsequently scaled up in a fixed bed reactor to validate the results on an integral and larger-scale reactor. On the other side, carbon product quality has been thoroughly determined by structural, textural, chemical and morphological characterization, finding significant differences between the 
carbon nanofilaments obtained, which reveals different growth mechanisms attributed to the size and crystal structure of the nickel particles (alloyed or not) depending on the textural promoter $\left(\mathrm{Al}_{2} \mathrm{O}_{3}\right.$ or $\left.\mathrm{MgO}\right)$ and the $\mathrm{Cu}$ loading used in the preparation of each catalyst.

\section{EXPERIMENTAL}

\subsection{Catalyst preparation}

Ni-based catalysts were prepared: $\mathrm{Ni} / \mathrm{Al}_{2} \mathrm{O}_{3}(\mathrm{Ni} / \mathrm{Al}$ molar ratio: $2: 1)$ and $\mathrm{Ni} / \mathrm{MgO}(\mathrm{Ni} / \mathrm{Mg}$ : 2:1), where $\mathrm{Ni}$ acts as active phase in the $\mathrm{CDM}$ process and $\mathrm{Al}_{2} \mathrm{O}_{3}$ and $\mathrm{MgO}$ as textural promoters. The molar ratio of the starting catalyst components $(2: 1)$ was selected according to prior works $[20,22]$. Catalysts were synthesized from mixture of the respective nitrates $\left(\mathrm{Ni}\left(\mathrm{NO}_{3}\right)_{2}, \mathrm{Al}\left(\mathrm{NO}_{3}\right)_{3}\right.$ or $\left.\mathrm{Mg}\left(\mathrm{NO}_{3}\right)_{2}\right)$ by the fusion method in air at $350{ }^{\circ} \mathrm{C}$ during $1 \mathrm{~h}$ and subsequent calcination at $450^{\circ} \mathrm{C}$ and $8 \mathrm{~h}[19,47]$. In parallel, $\mathrm{Cu}$-doped catalysts were prepared including $\mathrm{Cu}\left(\mathrm{NO}_{3}\right)_{2}$ in the synthesis. The fresh-catalyst powder was grounded and sieved to particles in 100-200 $\mu \mathrm{m}$ range, and then subjected to a reduction step. This last step was carried out in the CDM reactor (thermobalance or quartz reactor, as detailed in the next section), thus obtaining the final catalysts whose ID and nominal compositions can be seen in Table 1. Doped catalysts are hereafter denoted as $\mathrm{Ni}-\mathrm{Cu}(\mathrm{X}) / \mathrm{Al}$ or $\mathrm{Ni}-\mathrm{Cu}(\mathrm{X}) / \mathrm{Mg}$, where $\mathrm{X}$ refers to the final amount of $\mathrm{Cu}$ in molar percentage (content in the reduced catalyst): $2.5,5$, 7.5 or $10 \%$.

\subsection{Experimental facilities and CDM tests}

Catalysts were preliminarily tested in a thermobalance (CAHN TG-2151) at different temperatures and modes of operation: temperature programmed mode (using a heating rate of $10{ }^{\circ} \mathrm{C} \mathrm{min}^{-1}$ ) from $400{ }^{\circ} \mathrm{C}$ to $900{ }^{\circ} \mathrm{C}$ and isothermal mode (at $550,600,650,700$ and $750{ }^{\circ} \mathrm{C}$ for $10 \mathrm{~h}$ ) were used. The activity of each catalyst in the CDM reaction was recorded gravimetrically via the weight changes of the sample due to progressive carbon deposition as 
a reaction product, as previously reported in $[44,47]$. In a typical run, $10 \mathrm{mg}$ of fresh catalyst was previously reduced at $650{ }^{\circ} \mathrm{C}$ with a $\mathrm{H}_{2}$ flow rate of $1 \mathrm{l}_{\mathrm{N}} \mathrm{h}^{-1}$ until complete reduction of catalyst (until weight stabilization). Then, CDM reaction was carried out using a $\mathrm{CH}_{4}$ $(99.99 \%)$ flow rate of $11_{N} h^{-1}$, ensuring maximum carbon deposition and subsequent deactivation of the catalyst.

Secondly, a quartz fixed-bed reactor (FBR) of $18 \mathrm{~mm}$ i.d, $750 \mathrm{~mm}$ height and heated by an electric furnace, was used to evaluate and contrast at higher scale magnitude some selected catalysts. Prior to CDM tests, $50 \mathrm{mg}$ of fresh catalysts were subjected to a reduction treatment at $650{ }^{\circ} \mathrm{C}$ for $1 \mathrm{~h}$ with a $\mathrm{H}_{2}$ flow rate of $6 \mathrm{l}_{\mathrm{N}} \mathrm{h}^{-1}$. Then, the CDM reaction was carried out at 650 and $750{ }^{\circ} \mathrm{C}$ (isothermal mode) with a $\mathrm{CH}_{4}\left(99.99 \%\right.$ ) flow rate of $6 \mathrm{l}_{\mathrm{N}} \mathrm{h}^{-1}$ to obtain a WHSV (Weight Hourly Space Velocity, defined as the total flow rate per gram of fresh catalyst loaded) of $120 \mathrm{l}_{\mathrm{N}} \mathrm{g}_{\mathrm{cat}}{ }^{-1} \mathrm{~h}^{-1}$. The composition of the outlet gas from the FBR was determined by micro GC (HP Varian CP 4900) equipped with two packed columns (MS5 Molecular Sieve and Q-type Porapack) and a TCD.

The carbon produced was directly measured by substracting the catalyst amount, corresponding satisfactorily with the mass of carbon expected from the mass balance within an error of less than $5 \%$. On the other hand, an estimation of carbon accumulated, $g_{C}(\mathrm{~g})$, during CDM reaction was determined from the methane conversion $\left(\chi_{\mathrm{CH}_{4}}\right)$ evolution by the equation:

$$
g_{C}=\frac{M_{C}}{V_{m}} \int_{0}^{t} F_{C_{4}} \chi_{C_{4}} d t
$$

where $M_{C}$ is the carbon molar mass $\left(12.0107 \mathrm{~g} \mathrm{~mol}^{-1}\right), V_{m}$ is the $\mathrm{CH}_{4}$ molar volume $\left(1 \mathrm{~mol}^{-1}\right)$, $F_{C_{4}}\left(\mathrm{~h} \mathrm{~h}^{-1}\right)$ is the $\mathrm{CH}_{4}$ flow rate fed to the reactor, and $t(\mathrm{~h})$ is the run time. For comparison, $g_{C}$ is expressed as the carbon deposited with respect the amount of active phase in the catalysts: $\mathrm{Ni}$ or $\mathrm{Ni}+\mathrm{Cu}$ (when $\mathrm{Cu}$ is present in the catalyst formulation). 


\subsection{Characterization techniques}

The catalysts were characterized by X-ray diffraction (XRD) and temperature-programmed reduction (TPR), while the carbon nanofilaments quality obtained in CDM tests was determined using structural (XRD), textural ( $\mathrm{N}_{2}$ adsorption) and morphology characterization. Morphological appearance was performed by scanning electron (SEM; Hitachi S-3400N) and transmission electron microscopy (TEM; Tecnai F30 of FEI). TEM microscope is equipped with a cannon of $300 \mathrm{KeV}$ and a maximum resolution of $1.5 \AA$.

In addition, carbonaceous product composition was determined by elemental analysis (Thermo Scientific FlashEA 1112 analyzer) and inductively coupled plasma optical emission spectrometry (ICP-OES; Ametek Spectroblue).

X-ray diffractograms were acquired in a Bruker D8 Advance Series 2 diffractometer. The angle range scanned was $10^{\circ}-80^{\circ}$ using a counting step of $0.05^{\circ}$ and a counting time per step of $3 \mathrm{~s}$. XRD data were fitted using the structure analysis software TOPAS (Bruker AXS) and Rietveld refinement, which results in crystal structure information (lattice parameters) and macroscopic sample information (crystallite size and crystalline phase fractions). The graphite peak fit gave information on structural parameters such as interlayer spacing (or $d$-spacing), $d_{002}$, or mean crystallite size along c axis (transverse to the graphene planes), $L_{c}$. The mean interlayer spacing was evaluated from the position of the (002) peak applying Bragg's Law [48], while the mean crystallite size was calculated using the Scherrer formula, with a value of $K=0.89[48]$.

Physisorption isotherms were measured by $\mathrm{N}_{2}$ adsorption at $77 \mathrm{~K}$ in a Micromeritics ASAP2020 apparatus. BET specific surface area $\left(S_{B E T}\right)$ and micropore surface area $\left(S_{m i c}\right)$ were calculated by applying the BET and t-plot methods, respectively, to the $\mathrm{N}_{2}$ adsorption isotherms. Total pore volumes were measured at $\mathrm{p} / \mathrm{p}_{0}=0.99$. 
The reducibility of the fresh catalysts was studied by TPR. The respective reduction profiles were obtained in an AutoChem Analyzer II 2920 (Micromeritics) provided with a TCD from a sample amount of $10 \mathrm{mg}$ and using a heat rate of $5^{\circ} \mathrm{C} \mathrm{min}-1$ within a temperature range from room temperature to $1000^{\circ} \mathrm{C}$ under a flow rate of $50 \mathrm{ml} \mathrm{min}^{-1}$ of a $\mathrm{H}_{2}(10 \%) / A r$ mixture.

\section{RESULTS AND DISCUSSION}

\subsection{Catalysts characterization}

TPR profiles of fresh undoped and $\mathrm{Cu}$-doped catalysts and with different textural promoters $\left(\mathrm{Al}_{2} \mathrm{O}_{3}\right.$ or $\left.\mathrm{MgO}\right)$ are shown in Fig. 1 . At $650^{\circ} \mathrm{C}$ (the selected reduction temperature), the almost complete reduction of $\mathrm{Ni}^{\mathrm{II}}$ to $\mathrm{Ni}^{0}$ (peaks 1,2 and 3 , and peaks $1,5,6$ and 7 for $\mathrm{Al}_{2} \mathrm{O}_{3}$ and $\mathrm{MgO}$-based catalysts, respectively) and of $\mathrm{Cu}^{\mathrm{II}}$ to $\mathrm{Cu}^{0}$ (peak 4) is ensured prior to $\mathrm{CDM}$ tests. However, large differences are observed with respect to the textural promoter used: $\mathrm{Al}_{2} \mathrm{O}_{3}$-based catalysts (Fig. 1a) exhibit a better reducibility due to a less active phase/promoter interaction, while $\mathrm{MgO}$-catalysts (Fig. 1b) present a larger $\mathrm{H}_{2}$ consumption at temperatures above $650{ }^{\circ} \mathrm{C}$ (more accentuated in the case of the undoped catalyst). The latter would require a reduction at a higher temperature before CDM reaction; however, the use of reduction temperatures above $650{ }^{\circ} \mathrm{C}$ results in the Ni particle sintering giving place to particle sizes less active in the methane decomposition reaction $[49,50]$. The $\mathrm{Cu}$ presence leads to the formation of a $\mathrm{Cu}^{\mathrm{II}}$ to $\mathrm{Cu}^{0}$ reduction peak (peak 4) at low temperature $\left(170-175^{\circ} \mathrm{C}\right)$ and to the reduction of $\mathrm{Ni}^{\mathrm{II}}$ to $\mathrm{Ni}^{0}$ around $200{ }^{\circ} \mathrm{C}$, which is related to the formation of defects and dislocations in the $\mathrm{Ni}$ crystal lattice due to the incorporation of $\mathrm{Cu}$ atoms [51]. It has also been associated with the reduction of bulk $\mathrm{NiO}$ (unsupported) to $\mathrm{Ni}$ [52]. In both cases, reduction peaks shifted toward lower temperatures after $\mathrm{Cu}$ doping, indicating a higher reducibility of catalysts. This fact could be ascribed to a weaker interaction between metal particles and textural promoter due to a smaller metal oxide particles in the fresh doped catalyst $[30,31]$. 

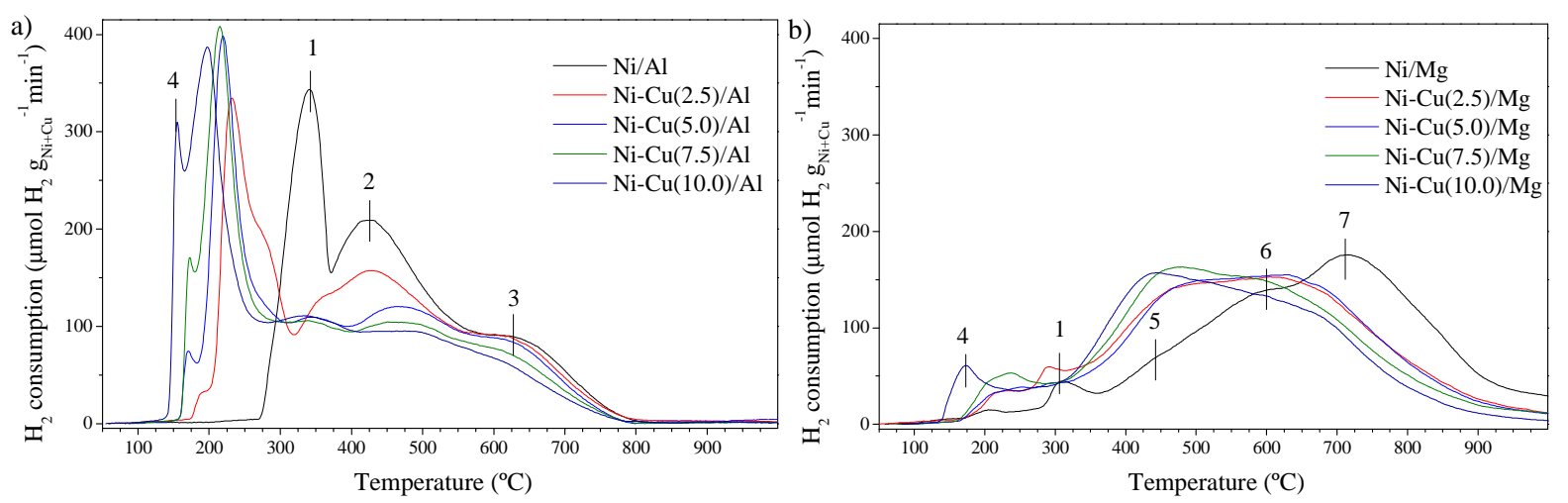

Fig. 1. Catalyst TPR profiles: undoped and doped at $10 \mathrm{~mol} \%$. a) $\mathrm{Al}_{2} \mathrm{O}_{3}$ and b) $\mathrm{MgO} .1=$ Bulk NiO $\rightarrow \mathrm{Ni} ; 2$ and $3=\mathrm{NiO}$ supported $\mathrm{Al}_{2} \mathrm{O}_{3} \rightarrow \mathrm{Al}_{2} \mathrm{O}_{3}+\mathrm{Ni} ; 4=\mathrm{CuO} \rightarrow \mathrm{Cu} ; 5,6$ and $7=$ $\mathrm{NiO}$ supported $\mathrm{MgO} \rightarrow \mathrm{MgO}+\mathrm{Ni}$

Diffractograms of reduced $\mathrm{Al}_{2} \mathrm{O}_{3}$ and $\mathrm{MgO}$-based catalysts are shown in Fig. 2a and $2 \mathrm{~b}$, respectively. Similarly, the phases and other structural information obtained by Rietveld refinement are compiled in Table 1 . In all cases, the reduction stage was carried out in thermobalance and was maintained at $650{ }^{\circ} \mathrm{C}$ until the weight stabilization of the catalyst (always before $60 \mathrm{~min}$ ), at which time the maximum possible reduction of $\mathrm{NiO}$ to $\mathrm{Ni}$ was obtained. Ni reflections attributed to planes (111), (200) and (220) at 44.5, 51.9 and $76.4^{\circ}$, respectively, of fcc system [53] are detected in all catalysts. In case of MgO-based catalysts, $\mathrm{MgO}$ and $\mathrm{NiO}$ fcc phases have been also detected revealing an insufficient reduction of the $\mathrm{NiO}$ from the fresh catalysts, as anticipated by TPR analysis (Fig. 1b). In both phases the plane reflection peaks appear at related angles: (111), (200), (220), (311) and (222) at 37.2, $43.3,62.7,75.3$ and $79.3^{\circ}$, respectively $[54,55]$. However, the relative intensity of the different planes is different, so depending on the intensity of the resulting peaks it is obvious to discount the exclusive presence of MgO. Strikingly, data fitting by Rietveld refinement showed the concurrence of two fcc Ni structures (named as Ni' and Ni" for differentiation) with different lattice constant (a) and/or crystal size, as can be seen in Table 1 and Fig. 3. The 
presence of nickel particles with different size and/or lattice constant will involve obtaining carbon nanofilaments of different diameter and graphitic stacking, as will be discussed in section 3.3.2. In case of $\mathrm{Al}_{2} \mathrm{O}_{3}$ catalysts, the size of both structures (and their lattice constants), Ni' and Ni”, as well as the weight fraction of smaller Ni particles (Ni') in the catalyst decreased as the $\mathrm{Cu}$ contain increased. The size and mass fraction of the Ni' phase fall from 8.4 to $6.5 \mathrm{~nm}$ and from 79.2 to $52.4 \%$ for undoped catalyst and that doped with $\mathrm{Cu}$ at $10 \%$, respectively. In contrast, $\mathrm{MgO}$ catalysts with lower $\mathrm{Cu}$ contents $(\leq 5 \%)$ presented a single structure and size of $\mathrm{Ni}$ in addition to the $\mathrm{NiO}$, and a bimodal size distribution for higher $\mathrm{Cu}$ contents (> $7.5 \%$ ). In addition, the fraction of $\mathrm{NiO}$ in the $\mathrm{MgO}$-catalysts decreased as the $\mathrm{Cu}$ content increased, which as seen above improves the reducibility of the catalyst.

On the other hand, the formation of solid solutions $\left(\mathrm{Ni}_{(\mathrm{x})} \mathrm{Cu}_{(1-\mathrm{x})}, \mathrm{Ni}_{(\mathrm{x})} \mathrm{Cu}_{(1-\mathrm{x})} \mathrm{O}_{(\mathrm{x})}\right.$ and $\left.\mathrm{Mg}_{(\mathrm{x})} \mathrm{Cu}_{(1-\mathrm{x})} \mathrm{O}_{(\mathrm{x})}\right)$ can be confirmed taking into account the lattice constant of the detected crystalline phases and their relation to the $\mathrm{Cu}$ amount in the catalysts (see Fig. 3). In this way, there is a linear relationship between $\mathrm{Ni}$ molar fraction ( $\mathrm{x}$ in the $\mathrm{Ni}_{(\mathrm{x})} \mathrm{Cu}_{(1-\mathrm{x})}$ structure) of the catalysts and the lattice constant, what is consistent with the Vegaard's law for solid solutions $[25,56] . \mathrm{Cu}$ doping increased the lattice constant of the $\mathrm{Ni}_{(\mathrm{x})} \mathrm{Cu}_{(1-\mathrm{x})}$ crystallites, however a greater intercalation of $\mathrm{Cu}$ atoms formed ever smaller crystalline particles but with a size distribution shifted towards the larger ones (Ni"). Also $\mathrm{Ni}_{(\mathrm{x})} \mathrm{Cu}_{(1-\mathrm{x})} \mathrm{O}_{(\mathrm{x})}$ and $\mathrm{Mg}_{(\mathrm{x})} \mathrm{Cu}_{(1-\mathrm{x})} \mathrm{O}_{(\mathrm{x})}$ crystallites presented higher lattice constants as the $\mathrm{Cu}$ content increased (Fig. 3b), what is motivated by the higher ionic radius of $\mathrm{Cu}^{2+}$ with respect to the ionic radios of $\mathrm{Ni}^{2+}$ or $\mathrm{Mg}^{2+}$ that it replaces in the crystal lattice [57]. 


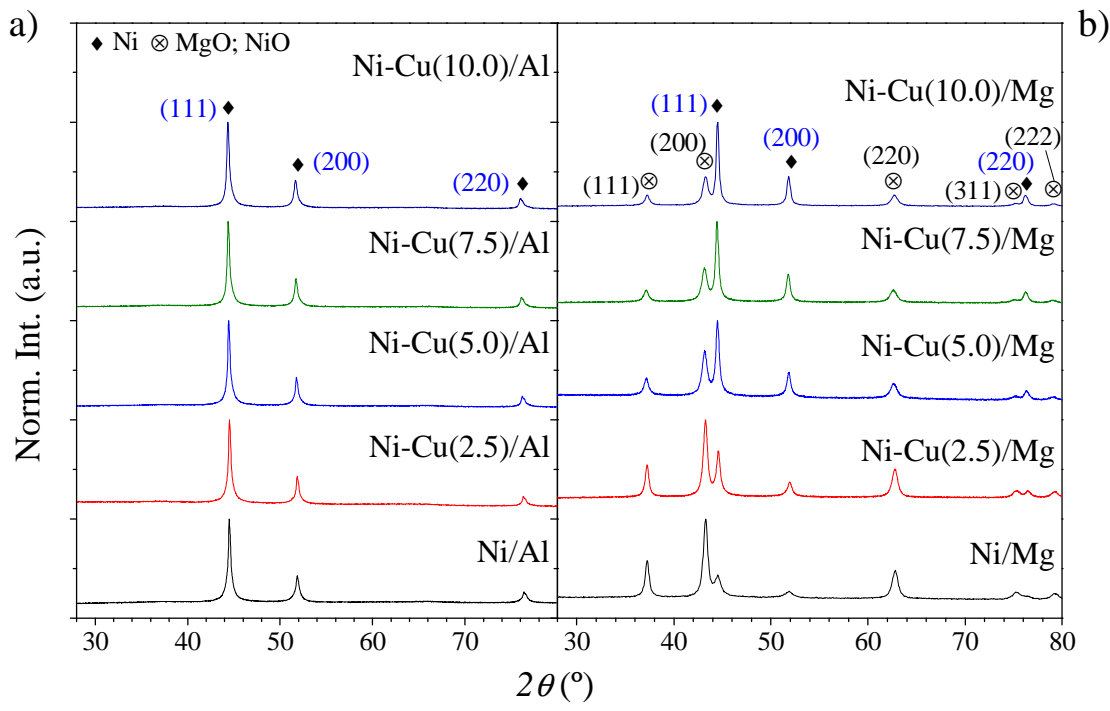

Fig. 2. Diffractograms of reduced catalyst at $650{ }^{\circ} \mathrm{C}$. a) $\mathrm{Al}_{2} \mathrm{O}_{3}$ - and b) $\mathrm{MgO}$-based catalysts.

Table 1. Crystallite sizes and fractions (of phase in the crystalline mixture) of the reduced catalysts.

\begin{tabular}{|c|c|c|c|c|c|c|c|c|c|}
\hline \multirow{2}{*}{ Catalyst } & \multirow{2}{*}{$\begin{array}{c}\begin{array}{c}\text { Nominal } \\
\text { composition } \\
(\text { mol. \%) }\end{array} \\
\end{array}$} & \multicolumn{2}{|c|}{$\mathrm{Ni}^{\prime}$} & \multicolumn{2}{|c|}{ Ni" } & \multicolumn{2}{|c|}{$\mathrm{NiO}$} & \multicolumn{2}{|c|}{ MgO } \\
\hline & & $(\mathrm{nm})$ & (wt. \%) & $(\mathrm{nm})$ & (wt. \%) & $(\mathrm{nm})$ & (wt. \%) & $(\mathrm{nm})$ & (wt. \%) \\
\hline $\mathrm{Ni} / \mathrm{Al}$ & $(67.0: 0.0: 33.0)$ & 8.4 & 79.2 & 51.7 & 20.8 & - & - & - & - \\
\hline $\mathrm{Ni}-\mathrm{Cu}(2.5) / \mathrm{Al}$ & (65.3: 2.5: 32.2) & 7.6 & 70.0 & 47.0 & 30.0 & - & - & - & - \\
\hline $\mathrm{Ni}-\mathrm{Cu}(5.0) / \mathrm{Al}$ & (63.7: 5.0: 31.4) & 7.0 & 66.4 & 43.9 & 33.6 & - & - & - & - \\
\hline $\mathrm{Ni}-\mathrm{Cu}(7.5) / \mathrm{Al}$ & (62.0: 7.5: 30.5) & 6.9 & 59.2 & 37.1 & 40.8 & - & - & - & - \\
\hline $\mathrm{Ni}-\mathrm{Cu}(10.0) / \mathrm{Al}$ & $(60.3: 10.0: 29.7)$ & 6.5 & 52.4 & 32.2 & 47.6 & - & - & - & - \\
\hline $\mathrm{Ni} / \mathrm{Mg}$ & (67.0: 0.0: 33.0) & 12.2 & 21.8 & - & - & 16.3 & 36.3 & 10.8 & 41.9 \\
\hline $\mathrm{Ni}-\mathrm{Cu}(2$ & $(65.3: 2.5: 32.2)$ & 14.0 & 28.4 & - & - & 15.4 & 31.2 & 10.6 & 40.4 \\
\hline $\mathrm{Ni}-\mathrm{Cu}(5.0) / \mathrm{Mg}$ & (63.7: $5.0: 31.4)$ & 15.7 & 34.0 & - & - & 12.1 & 28.0 & 10.0 & 38.0 \\
\hline $\mathrm{Ni}-\mathrm{Cu}(7.5) / \mathrm{Mg}$ & (62.0: $7.5: 30.5)$ & 13.5 & 31.1 & 38.0 & 10.0 & 11.1 & 23.8 & 9.7 & 35.1 \\
\hline $\mathrm{Ni}-\mathrm{Cu}(10.0) / \mathrm{Mg}$ & $(60.3: 10.0: 29.7)$ & 10.9 & 24.3 & 36.1 & 21.0 & 10.6 & 21.8 & 9.1 & 32.9 \\
\hline
\end{tabular}
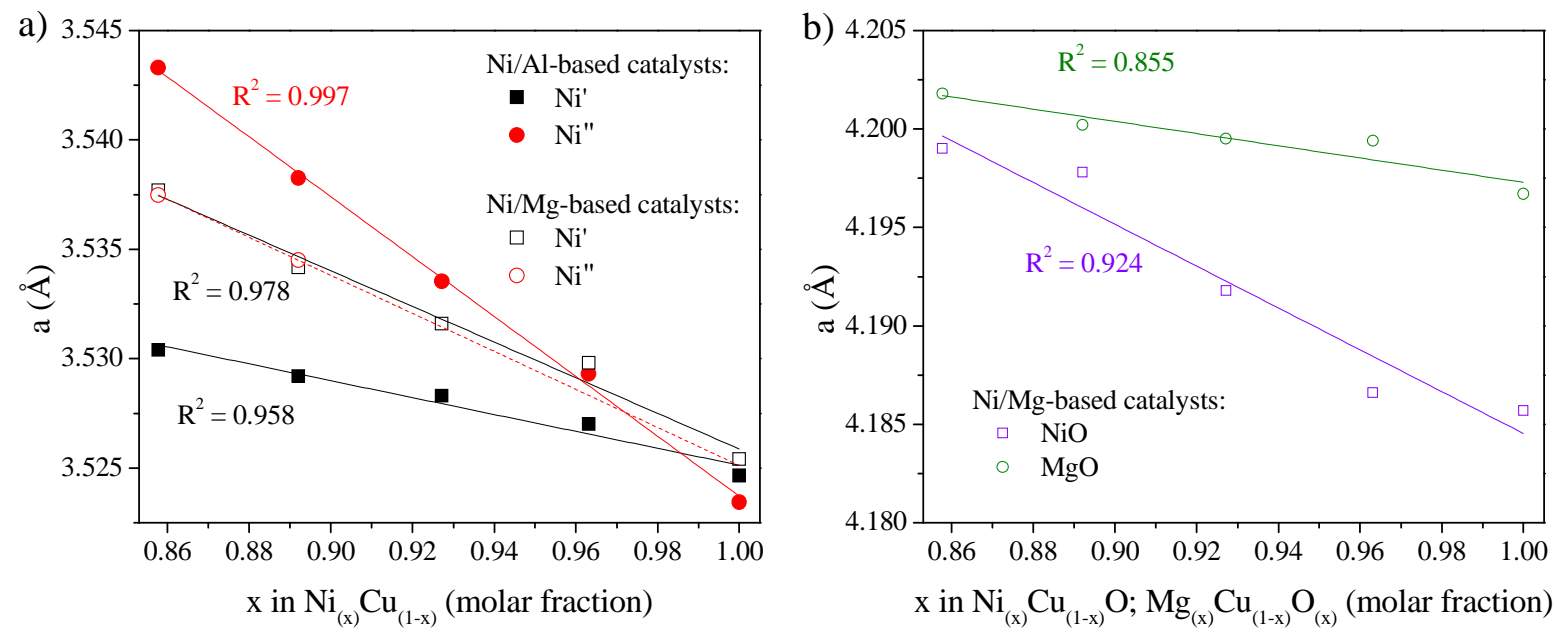
Fig. 3 Lattice constants as a function of the Ni molar fraction.

\subsection{CDM thermogravimetric analysis of Ni-based catalysts}

\subsubsection{Temperature-programmed CDM tests}

Catalysts (listed in Table 1) were tested in the CDM reaction in thermobalance and temperature-programmed mode, allowing the direct comparison of their activity towards the carbon and hydrogen formation. In Fig. 4 the effect of $\mathrm{Cu}$ doping in the carbon formation as a function of temperature for $\mathrm{Al}_{2} \mathrm{O}_{3}$ and $\mathrm{MgO}$-based catalysts can be observed. Table 2 shows the cumulative maximum carbon values $\left(C_{\max }\right)$ of each catalyst as well as the temperature at which it is reached, which is the deactivation temperature $\left(T_{d}\right)$ of the catalyst. In general, all catalysts showed activity in the $\mathrm{CDM}$, which starts around $450{ }^{\circ} \mathrm{C}$, obtaining with the undoped catalysts similar catalytic results indistinctly of the textural promoter used: a $C_{\max }$ of 28.2-30.4 $\mathrm{g} \cdot \mathrm{g}_{\mathrm{Ni}}{ }^{-1}$, which corresponds to a $\mathrm{H}_{2}$ formation of 4.7-5.1 $\mathrm{g} \cdot \mathrm{g}_{\mathrm{Ni}}{ }^{-1}$, and a maximum carbon formation rate $(C F R)$ of $0.042-0.044 \mathrm{~g} \cdot \mathrm{g}_{\mathrm{Ni}}{ }^{-1} \cdot \mathrm{s}^{-1} \cdot \mathrm{Cu}$ doping resulted in an increase in $C_{\max }$ and in the possibility of working at higher operating temperatures (in the range: 750 $875^{\circ} \mathrm{C}$; see $T_{d}$ and $T_{\text {CFRmax }}$ values in Table 2). This effect was more pronounced for the MgO-catalysts, which contain 3.7-4.7 wt. \% more $\mathrm{Ni}$ than $\mathrm{Al}_{2} \mathrm{O}_{3}$-catalysts. Thus, although $\mathrm{MgO}$-catalysts are incompletely reduced, the $\mathrm{NiO}$ still present in the catalyst could be reduced during the reaction improving their efficiencies at high temperature [58]. According to the XRD analysis of the catalysts (Fig. 2), the proportion of larger particles in the catalyst (Ni" particles in Table 1) is higher for higher $\mathrm{Cu}$ contents, which results in the formation of wider carbon nanofilaments improving the carbon formation. Catalysts doped at $7.5 \%$ formed the largest amount of carbon for the two textural promoters studied and were selected for further studies at both isothermal mode in thermobalance and in a FBR. 

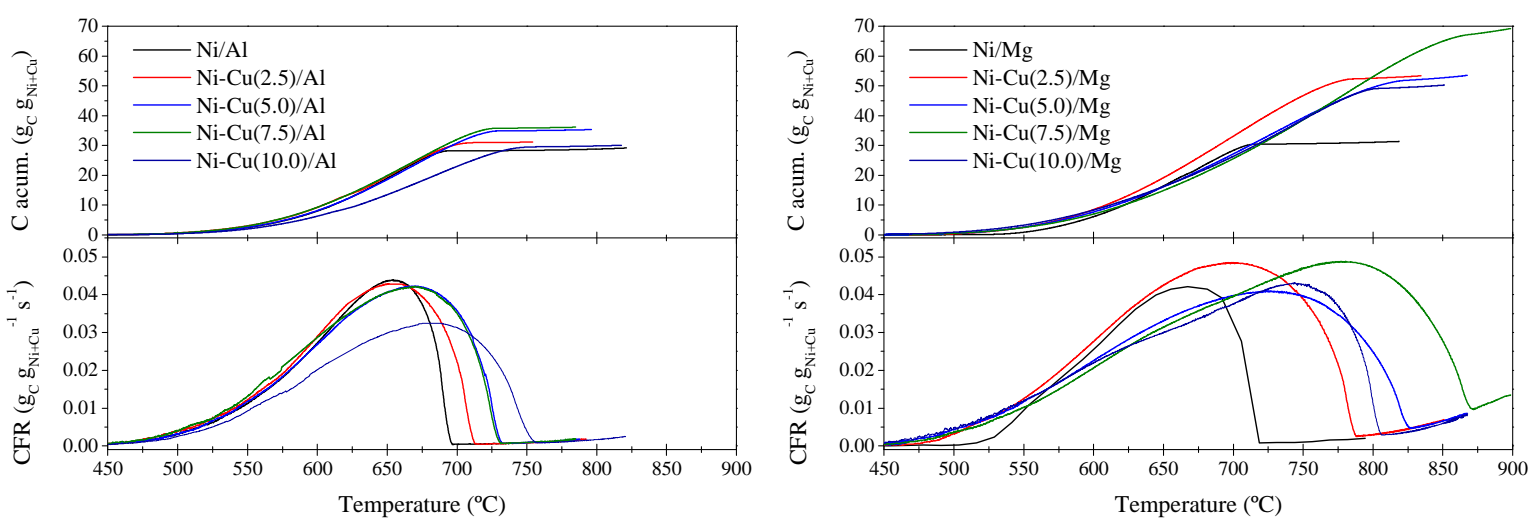

Fig. 4. Accumulated carbon and CFR as a function of temperature for a) $\mathrm{Al}_{2} \mathrm{O}_{3}$ and b) $\mathrm{MgO}$ based catalysts. Temperature-programmed mode CDM.

Table 2. Cumulative maximum carbon and maximum CFR values, and associated temperatures, for $\mathrm{Al}_{2} \mathrm{O}_{3}$ and $\mathrm{MgO}$-based catalysts. Temperature-programmed mode CDM.

\begin{tabular}{l|cc|cc}
\hline Catalyst & $\begin{array}{c}\boldsymbol{C}_{\text {max }} \\
\left(\mathrm{g}_{\mathrm{C}} \mathrm{g}_{\mathrm{Ni}+\mathrm{Cu}}{ }^{-1}\right)\end{array}$ & $\begin{array}{c}\boldsymbol{T}_{\boldsymbol{d}} \\
\left({ }^{\circ} \mathrm{C}\right)\end{array}$ & $\begin{array}{c}\boldsymbol{C F}_{\boldsymbol{m a x}} \\
\left(\mathrm{g}_{\mathrm{C}} \cdot \mathrm{g}_{\mathrm{Ni}+\mathrm{Cu}}{ }^{-1} \cdot \mathrm{s}^{-1}\right)\end{array}$ & $\begin{array}{c}\boldsymbol{T}_{\text {CFRmax }}{ }^{a} \\
\left({ }^{\circ} \mathrm{C}\right)\end{array}$ \\
\hline $\mathrm{Ni} / \mathrm{Al}$ & 28.2 & 692.7 & 0.044 & 654.0 \\
\hline $\mathrm{Ni}-\mathrm{Cu}(2.5) / \mathrm{Al}$ & 31.0 & 710.6 & 0.043 & 655.9 \\
$\mathrm{Ni}-\mathrm{Cu}(5.0) / \mathrm{Al}$ & 34.9 & 727.3 & 0.042 & 669.0 \\
$\mathrm{Ni}-\mathrm{Cu}(7.5) / \mathrm{Al}$ & 35.8 & 729.3 & 0.042 & 669.6 \\
$\mathrm{Ni}-\mathrm{Cu}(10.0) / \mathrm{Al}$ & 29.5 & 748.1 & 0.033 & 684.6 \\
\hline $\mathrm{Ni} / \mathrm{Mg}$ & 30.4 & 713.3 & 0.042 & 667.3 \\
$\mathrm{Ni}-\mathrm{Cu}(2.5) / \mathrm{Mg}$ & 52.3 & 784.9 & 0.048 & 700.0 \\
$\mathrm{Ni}-\mathrm{Cu}(5.0) / \mathrm{Mg}$ & 51.8 & 822.3 & 0.041 & 726.6 \\
$\mathrm{Ni}-\mathrm{Cu}(7.5) / \mathrm{Mg}$ & 67.4 & 871.4 & 0.049 & 777.0 \\
$\mathrm{Ni}-\mathrm{Cu}(10.0) / \mathrm{Mg}$ & 49.0 & 800.5 & 0.043 & 742.8 \\
\hline
\end{tabular}

\subsubsection{Isothermal-mode CDM tests}

$\mathrm{CDM}$ was carried out for $\mathrm{Ni} / \mathrm{Al}, \mathrm{Ni}-\mathrm{Cu}(7.5) / \mathrm{Al}, \mathrm{Ni} / \mathrm{Mg}$ and $\mathrm{Ni}-\mathrm{Cu}(7.5) / \mathrm{Mg}$ catalysts in isothermal mode at temperatures between 550 and $750^{\circ} \mathrm{C}$. Fig. 5 shows both $C_{\max }$ (a) and $C F R_{\max }$ (b) versus both time in which they are reached and operating temperature. Runs were carried out until the mass gain was almost negligible, reaching at that point both $C_{\max }$ and the deactivation time $\left(t_{d}\right)$. In general, catalysts obtained a higher carbon formation (and consequently a higher production of $\left.\mathrm{H}_{2}\right)$ at lower operating temperatures $\left(550{ }^{\circ} \mathrm{C}\right)$, where they also showed longer activity times until full deactivation. In contrast, $\mathrm{Ni}-\mathrm{Cu}(7.5) / \mathrm{Mg}$ reached 
an maximum of $C_{\max }$ at a higher temperature $\left(650^{\circ} \mathrm{C}\right)$ after a longer time of activity. As clearly seen in Fig. 5a, Cu-doped catalysts, independently of the textural promoter used, showed higher carbon yields and longer times of activity at any operating temperature. Likewise, doped catalysts exhibited activity at temperatures at which undoped catalysts did not (above 700 and $600{ }^{\circ} \mathrm{C}$ for $\mathrm{Ni} / \mathrm{Al}$ and $\mathrm{Ni} / \mathrm{Mg}$, respectively). Higher operating temperatures in the CDM reaction allow achieving a greater methane conversion by solving the thermodynamic limitations imposed by the low temperatures, and the formation of carbon nanofilaments with a higher graphitization degree [2]. Regarding the $C F R_{\max }$, it increased as the temperature did for all catalysts. Moreover, $\mathrm{Al}_{2} \mathrm{O}_{3}$-based catalysts showed higher $\mathrm{CFR}_{\max }$ at any operating temperature even though it was needed longer times to reach those values, as compared to $\mathrm{MgO}$-based catalysts. $\mathrm{Cu}$-catalysts, in addition to offering the aforementioned possibility of working at higher temperatures, did not result in noticeable differences in the $\mathrm{CFR}_{\max }$ but they achieved it in less time at low temperature $\left(550\right.$ and $\left.600{ }^{\circ} \mathrm{C}\right)$.

Finally, although it is not possible to directly compare the results of the two thermobalance operation modes (temperature-programmed and isothermal), similar (same order) $C_{\max }$ and $C F R_{\max }$ values are obtained. The comparative behavior between catalysts in temperatureprogrammed tests is extrapolated at isothermal mode; however, it is easier to observe the effect of the temperature in the latter, although the $\mathrm{MgO}$-based catalysts did not reach at any temperature the values recorded in temperature-programmed mode, which could be due to their lower recorded $C F R_{\text {max }}$ compared to those $\mathrm{Al}_{2} \mathrm{O}_{3}$-based catalysts (see Fig. 5b). 
a)

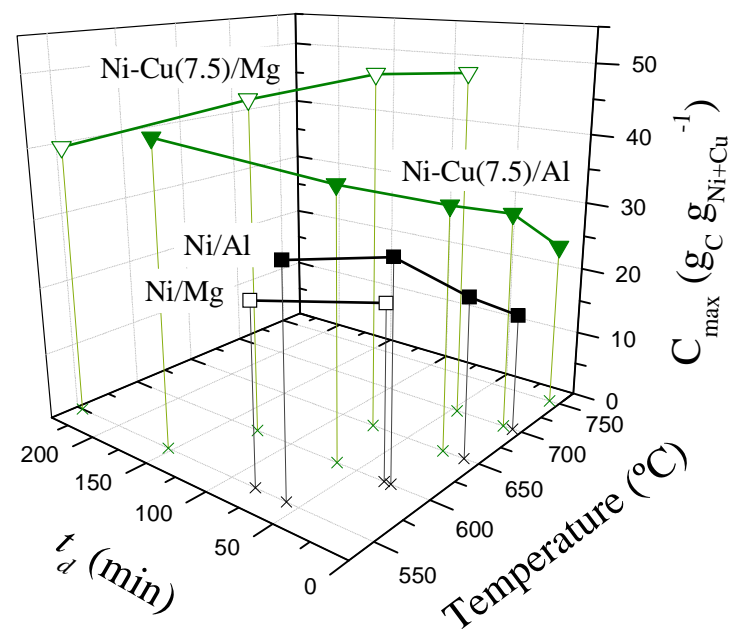

b)

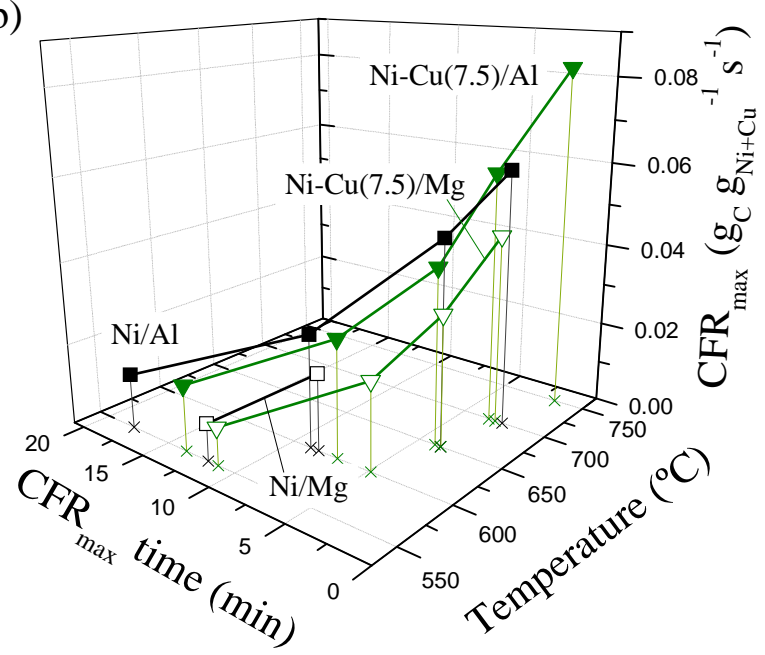

Fig. 5. a) Accumulated carbon until the catalyst deactivation per gram of active phase $(\mathrm{Ni}+\mathrm{Cu})$ and b) maximum $C F R$, both as a function of time ( $t_{d}$ and time to $C F R_{\max }$, respectively) and temperature of the Isothermal-mode CDM test. Results are shown only for temperatures at which the catalysts were active in the range $550-750{ }^{\circ} \mathrm{C}$.

\subsection{Fixed-bed CDM tests}

\subsubsection{Catalytic performance in hydrogen production}

Once the catalysts were tested in thermobalance, $\mathrm{Cu}$-doped catalysts selected in previous section and undoped ones ( $\mathrm{Ni} / \mathrm{Al}, \mathrm{Ni}-\mathrm{Cu}(7.5) / \mathrm{Al}, \mathrm{Ni} / \mathrm{Mg}$ and $\mathrm{Ni}-\mathrm{Cu}(7.5) / \mathrm{Mg}$ ) were used in a FBR in 120 min CDM tests. In this set-up, the WHSV used in thermobalance $\left(100 l_{N} g_{c a t}{ }^{-1} h^{-1}\right)$ is increased to $120 \mathrm{l}_{\mathrm{N}} \mathrm{g}_{\mathrm{cat}}{ }^{-1} \mathrm{~h}^{-1}$, in addition to improve the gas-catalyst contact, since in thermobalance, a part of inlet gas crosses the sample basket zone without an effective contact with the sample. Methane conversion and carbon accumulation data at operating temperatures of 650 and $750{ }^{\circ} \mathrm{C}$ are shown in Fig. 6 and Fig. 7, respectively. Initial $\mathrm{CH}_{4}$ conversions between 30 and $40 \%$ were registered for all catalysts at an operating temperature of $650{ }^{\circ} \mathrm{C}$ (Fig. 6a). However, Cu-doped catalysts showed a more stable activity during the CDM reaction. Undoped catalysts lost most of their activity after 30 min of reaction. This behavior can be observed more clearly when the carbon accumulation obtained by these catalysts is taking into account (Fig. 6b). At higher temperatures $\left(750^{\circ} \mathrm{C}\right.$, Fig. 7$)$ a greater activity 
towards the methane decomposition and inherent carbon formation is promoted, but the activity time of the catalyst is shortened significantly. In this case, only the doped catalysts showed higher initial conversions $(52-55 \%)$. Since these catalysts present a higher initial methane conversion, the hydrogen produced during reaction could lead to the gasification of the carbon product when its concentration is high enough [59]. However, this is minimized in this work by using pure methane as feedstock, thus hindering the reaction displacement towards the methane formation, and the high WHSV used through a catalyst bed of a very small height. A longer gas/solid contact time during reaction influences the structural and textural properties of the generated carbon nanofilaments for feedstocks with high $\mathrm{H}_{2}$ concentration $[25,59]$. In any case, all the catalysts lost their activity after 10 min of reaction due to the blockage of their active sites. Despite the carbon diffusion mechanism of the catalysts (as will be elucidated later), the higher activity of $\mathrm{Ni}$ at $750{ }^{\circ} \mathrm{C}$ promotes the methane decomposition at a faster rate than the carbon diffusion on or through the particle, what generates encapsulating carbon formation (seen by TEM) and, finally, the catalyst deactivation [7]. There are also changes in the chemistry of the $\mathrm{Ni}_{(\mathrm{x})} \mathrm{Cu}_{(1-\mathrm{x})}$ alloy particle that reduce its catalytic activity at high temperature [60]. This early loss of activity resulted in less carbon formation as the reaction proceeded (Fig. $7 \mathrm{~b}$ ). Therefore, after $2 \mathrm{~h}$ of reaction, the final formation of $\mathrm{H}_{2}$ and carbon was much lower at $750^{\circ} \mathrm{C}$, as can be seen in the data listed in Table 3. It is understood that these activity losses could be avoided by working at lower WHSV of methane. However, at $750{ }^{\circ} \mathrm{C}$, as already anticipated by thermobalance (Section 3.2), $\mathrm{MgO}$ catalysts showed a better yield in the CDM reaction than those based on $\mathrm{Al}_{2} \mathrm{O}_{3}$, which were more active at $650{ }^{\circ} \mathrm{C}$. Note that for lower temperatures the rate of carbon (or hydrogen) formation is lower and that $\mathrm{MgO}$-catalysts still need more time to reach their $C_{\max }$ (as previously seen in thermobalance in Fig. 5). In this sense, at $650{ }^{\circ} \mathrm{C}$ and $\mathrm{FBR}$, 
$\mathrm{MgO}$-catalysts can also lead to a higher carbon formation than $\mathrm{Al}_{2} \mathrm{O}_{3}$-based ones for reaction times longer than $120 \mathrm{~min}$.
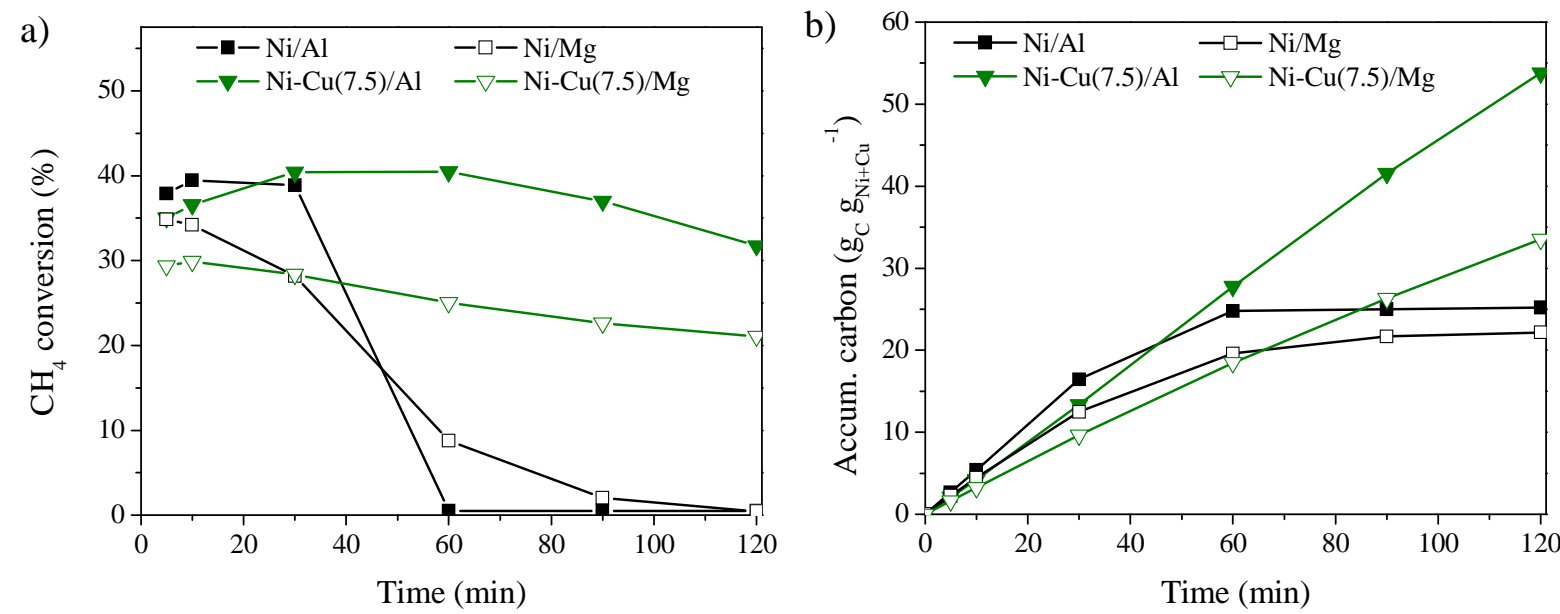

Fig. 6. a) Methane conversion and b) accumulated carbon during $\mathrm{CDM}$ tests at $650^{\circ} \mathrm{C}$. Isothermal mode CDM tests in FBR.
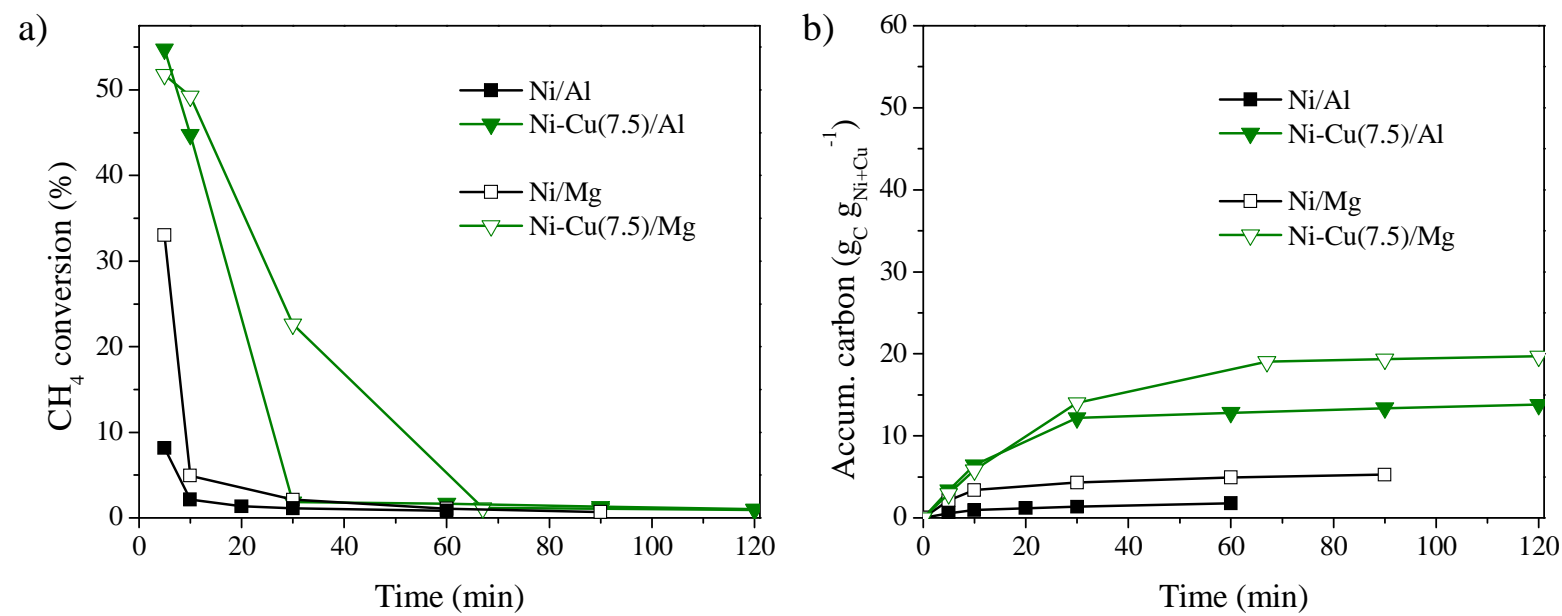

Fig. 7. a) Methane conversion and b) accumulated carbon during $\mathrm{CDM}$ tests at $750{ }^{\circ} \mathrm{C}$. Isothermal mode CDM tests in FBR.

Table 3. Carbon and $\mathrm{H}_{2}$ total formation after $2 \mathrm{~h}$ runs at 650 and $750{ }^{\circ} \mathrm{C}$.

\begin{tabular}{l|cc|cc}
\hline \multicolumn{1}{c|}{ Catalyst } & \multicolumn{2}{|c|}{$\mathbf{C D M}$ at $650^{\circ} \mathbf{C}$} & \multicolumn{2}{c}{$\mathbf{C D M}$ at $750{ }^{\circ} \mathbf{C}$} \\
& $\mathbf{C}(\mathrm{g})$ & $\mathbf{H}_{\mathbf{2}}\left(\mathrm{l}_{\mathrm{N}}\right)$ & $\mathbf{C}(\mathrm{g})$ & $\mathbf{H}_{\mathbf{2}}\left(\mathrm{l}_{\mathrm{N}}\right)$ \\
\hline $\mathrm{Ni} / \mathrm{Al}$ & 0.80 & 3.3 & 0.13 & 0.5 \\
$\mathrm{Ni}-\mathrm{Cu}(7.5) / \mathrm{Al}$ & 2.10 & 8.9 & 0.43 & 1.8 \\
$\mathrm{Ni} / \mathrm{Mg}$ & 0.77 & 3.2 & 0.22 & 0.9 \\
$\mathrm{Ni}-\mathrm{Cu}(7.5) / \mathrm{Mg}$ & 1.46 & 6.2 & 0.73 & 3.0 \\
\hline
\end{tabular}




\subsubsection{Carbon nanofilaments characterization}

Nanostructured carbon materials obtained in FBR at $650{ }^{\circ} \mathrm{C}$ were analyzed chemically, structurally, texturally and morphologically by elemental analysis and ICP-OES, XRD, $\mathrm{N}_{2}$ physisorption and SEM and TEM, respectively. Chemical analysis results, summarized in Table 4, verify the high carbon content (>96.37 wt. \%) in the carbonaceous products (accumulated carbon + catalyst) obtained after the CDM tests. The low oxygen content $(<0.52$ wt. \%) measured also stands out. Obviously, the carbonaceous samples obtained with undoped catalysts had a higher ash content (catalyst) but below 3.11 wt. \%. Similarly, according to the textural properties determined by $\mathrm{N}_{2}$ physisorption at $77 \mathrm{~K}$ and listed in Table 5, the BET specific surface areas $\left(S_{B E T}\right)$ increased as the catalyst content in products decreased: $\quad \mathrm{Ni} / \mathrm{Mg}=84 \mathrm{~m}^{2} \mathrm{~g}^{-1}, \quad \mathrm{Ni} / \mathrm{Al}=90 \mathrm{~m}^{2} \mathrm{~g}^{-1}, \quad \mathrm{Ni}-\mathrm{Cu}(7.5) / \mathrm{Mg}=135 \mathrm{~m}^{2} \mathrm{~g}^{-1} \quad$ and $\mathrm{Ni}-\mathrm{Cu}(7.5) / \mathrm{Al}=140 \mathrm{~m}^{2} \mathrm{~g}^{-1}$. In each case, the resultant $S_{B E T}$ is a compromise between the carbon fraction in the product and its nanofilament diameter distribution, since a narrower diameter distribution results in a higher $S_{\mathrm{BET}}[61,62]$. In addition, carbonaceous products obtained from $\mathrm{Cu}$-doped catalysts also presented higher micropore surface areas $\left(S_{m i c}\right)$, which are attributed to surface defects and graphene edges in the nanofilament outer surface or stacking exposed areas. The calculated total pore volume $\left(V_{t}\right)$ was very similar in all cases.

Table 4. Elemental composition results of the carbonaceous products obtained in FBR at $650^{\circ} \mathrm{C}$

\begin{tabular}{l|cccccc|cccc}
\hline \multirow{2}{*}{ Growth catalyst } & \multicolumn{9}{|c|}{ Elemental Analysis (wt. \%) } & \multicolumn{4}{c}{ ICP-OES (wt. \%) } \\
& $\mathrm{C}$ & $\mathrm{H}$ & $\mathrm{N}$ & $\mathrm{S}$ & $\mathrm{O}$ & Ashes & $\mathrm{Ni}$ & $\mathrm{Cu}$ & $\mathrm{Al}$ & $\mathrm{Mg}$ \\
\hline $\mathrm{Ni} / \mathrm{Al}$ & 96.70 & 0.13 & 0.03 & 0.00 & 0.30 & 2.84 & 2.90 & 0.00 & 0.76 & 0.00 \\
$\mathrm{Ni}-\mathrm{Cu}(7.5) / \mathrm{Al}$ & 98.46 & 0.22 & 0.03 & 0.00 & 0.34 & 0.95 & 1.19 & 0.15 & 0.30 & 0.00 \\
$\mathrm{Ni} / \mathrm{Mg}$ & 96.37 & 0.11 & 0.00 & 0.00 & 0.41 & 3.11 & 3.28 & 0.00 & 0.00 & 0.66 \\
$\mathrm{Ni}-\mathrm{Cu}(7.5) / \mathrm{Mg}$ & 96.66 & 0.28 & 0.00 & 0.00 & 0.52 & 2.54 & 1.98 & 0.25 & 0.00 & 0.35 \\
\hline
\end{tabular}

Table 5. Textural parameters of the carbonaceous products obtained in FBR at $650{ }^{\circ} \mathrm{C}$. 


\begin{tabular}{|c|c|c|c|}
\hline Growth catalyst & $\begin{array}{c}S_{B E T}{ }^{\mathbf{a}} \\
\left(\mathrm{m}^{2} \mathrm{~g}^{-1}\right)\end{array}$ & $\begin{array}{c}S_{\text {mic }}{ }^{\mathbf{b}} \\
\left(\mathrm{m}^{2} \mathrm{~g}^{-1}\right)\end{array}$ & $\begin{array}{c}\boldsymbol{V}_{t}^{\mathbf{c}} \\
\left(\mathrm{cm}^{3} \mathrm{~g}^{-1}\right)\end{array}$ \\
\hline $\mathrm{Ni} / \mathrm{Al}$ & 90 & 16 & 0.29 \\
\hline $\mathrm{Ni}-\mathrm{Cu}(7.5) / \mathrm{Al}$ & 140 & 40 & 0.28 \\
\hline $\mathrm{Ni} / \mathrm{Mg}$ & 84 & 19 & 0.26 \\
\hline $\mathrm{Ni}-\mathrm{Cu}(7.5) / \mathrm{Mg}$ & 135 & 49 & 0.35 \\
\hline
\end{tabular}

As for the carbon structure, it shows in all cases the graphite stacking formation, whose main plane (002) appears about $26.1-26.4^{\circ}$ in the diffractograms shown in Fig. 8. There is a displacement (around $0.19-0.23^{\circ}$ ) of the (002) peak towards higher $2 \theta$ angles in the nanofilaments obtained with $\mathrm{Cu}$-doped catalysts, which corresponds to a lower $d_{002}$. This fact can be correlated with the lattice constant of the $\mathrm{Ni}_{(\mathrm{x})} \mathrm{Cu}_{(1-\mathrm{x})}$ alloy in the starting catalyst (Fig. 3): it increased as the $\mathrm{Cu}$ content did becoming more precise the crystallographic similarity of the (111) alloy and the (002) graphite faces [17]. In addition, the crystal size of the (002) stack, $L_{c}$, grew in carbon nanofilaments obtained from doped catalysts. In addition to the graphite related peaks, the aforementioned (002) plane and the (100), (101), (004) and (110) planes [63], crystalline phases ( $\mathrm{Ni}$ and $\mathrm{MgO}$ and/or $\mathrm{NiO}$ ) from the used catalysts were also detected.

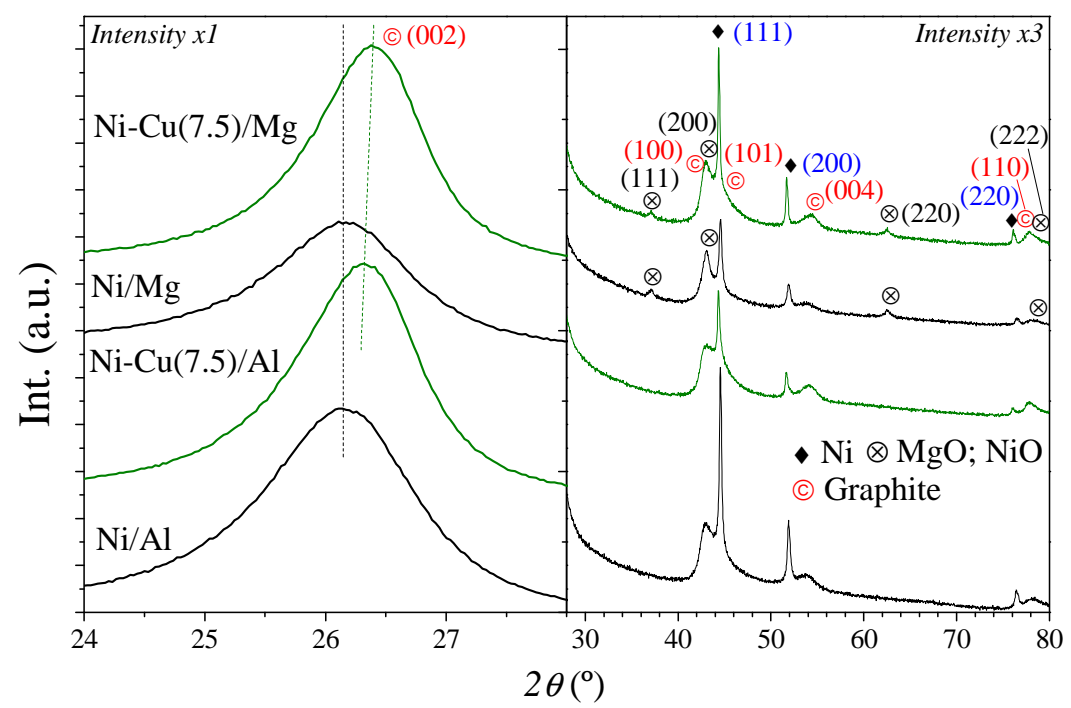

Fig. 8. Diffractograms of the carbonaceous products obtained in $\mathrm{FBR}$ at $650{ }^{\circ} \mathrm{C}$. Intensities have been magnified (Intensity x3) from a $2 \theta$ of $28^{\circ}$. 
Table 6. Structural parameters of the carbonaceous products obtained in FBR at $650{ }^{\circ} \mathrm{C}$.

\begin{tabular}{lccc}
\hline Growth catalyst & 2 $\boldsymbol{\theta}$ Pos. $\left({ }^{\circ}\right)$ & $\boldsymbol{d}_{\boldsymbol{0 0 2}}(\mathrm{nm})$ & $\boldsymbol{L}_{\boldsymbol{c}}(\mathrm{nm})$ \\
\hline $\mathrm{Ni} / \mathrm{Al}$ & 26.14 & 0.3407 & 5.6 \\
$\mathrm{Ni}-\mathrm{Cu}(7.5) / \mathrm{Al}$ & 26.33 & 0.3382 & 7.1 \\
$\mathrm{Ni} / \mathrm{Mg}$ & 26.17 & 0.3402 & 6.0 \\
$\mathrm{Ni}-\mathrm{Cu}(7.5) / \mathrm{Mg}$ & 26.40 & 0.3374 & 7.9 \\
\hline
\end{tabular}

SEM and TEM micrographs of the carbon nanofilaments produced in FBR are shown in Fig. 9 and Fig. 10, respectively. At first glance, SEM shows the bulk appearance of the samples revealing significant differences in aspect ratios: undoped $\mathrm{Al}_{2} \mathrm{O}_{3}$-based catalyst (Fig. 9a) led to the formation of wider and longer carbon nanofilaments than those obtained on the undoped MgO-based catalyst (Fig. 9c). Likewise, and in accordance with the highest carbon formation observed during the CDM tests (see Section 3.3.1.), Cu-doped catalysts formed wider carbon nanofilaments and with certain heterogeneity in diameters (Fig. 9b and Fig. 9d for $\mathrm{Al}_{2} \mathrm{O}_{3}$ and $\mathrm{MgO}$, respectively). Carbon nanofilaments observed by TEM (Fig. 10) correspond mainly to fishbone-type carbon nanofibers, consisting of stacked graphene cones, although the formation of multi-wall CNT (MWCNT) over the Ni/Mg catalyst was also confirmed. CNF obtained presented appreciable differences between samples: the angle between the graphene stacks and the growth axis of the nanofilament $(\alpha)$, the diameter, the length and the formation or not of an inner hollow. The angle $\alpha$, motivated by the shape of the $\mathrm{Ni}_{(\mathrm{x})} \mathrm{Cu}_{(1-\mathrm{x})}$ catalytic particle during the reaction, is almost completely opened in the nanofibers obtained with doped catalysts (Fig. 10c-d and Fig. 10g-h, for $\mathrm{Ni}-\mathrm{Cu}(7.5) / \mathrm{Al}$ and $\mathrm{Ni}-\mathrm{Cu}(7.5) / \mathrm{Mg}$, respectively), what is due to the involvement of large blunt particles. On the contrary, small particles form nanofilaments with more closed angles (fishbone CNF) or almost parallel to their growth axis (CNT) when the diffusion occurs in elongated particles. The formation of one or another of these last two structures is due to the type of carbon 
diffusion: through the catalytic particle (bulk diffusion) to form CNF or along its surface (surface diffusion) to form CNT [64]. In addition, carbon nanofilaments obtained from doped catalysts were wider and shorter with respect to its undoped counterparts (Fig. 10a-b and Fig. 10e-f, for $\mathrm{Ni} / \mathrm{Al}$ and $\mathrm{Ni} / \mathrm{Mg}$, respectively) as a result of a higher carbon formation. A high CFR motivates less controlled growth with the formation of big structures (diameters above $100 \mathrm{~nm}$ ) and the shortening of them. On the other hand, MWCNT obtained from Ni/Mg presented an inner hollow core (Fig. 10f), whose formation has been ascribed to the effect of the size of the catalytic particle and to the metal-support interaction strength [4]. However, it is conditioned by the type of diffusion given: bulk or surface, related to the carbon diffusion rate in the catalytic particle [64-66]: a high diffusion rate (e.g. due to higher operating temperatures) or a surface diffusion result in the hollow core formation. Summing up and according to the above, $\mathrm{Cu}$ doping forms a $\mathrm{Ni}_{(\mathrm{x})} \mathrm{Cu}_{(1-\mathrm{x})}$ alloy with a higher lattice constant that would favor the carbon diffusion through the particle, which promotes an increase in the carbon formation rate as well in the formation of denser carbon nanofilaments. 


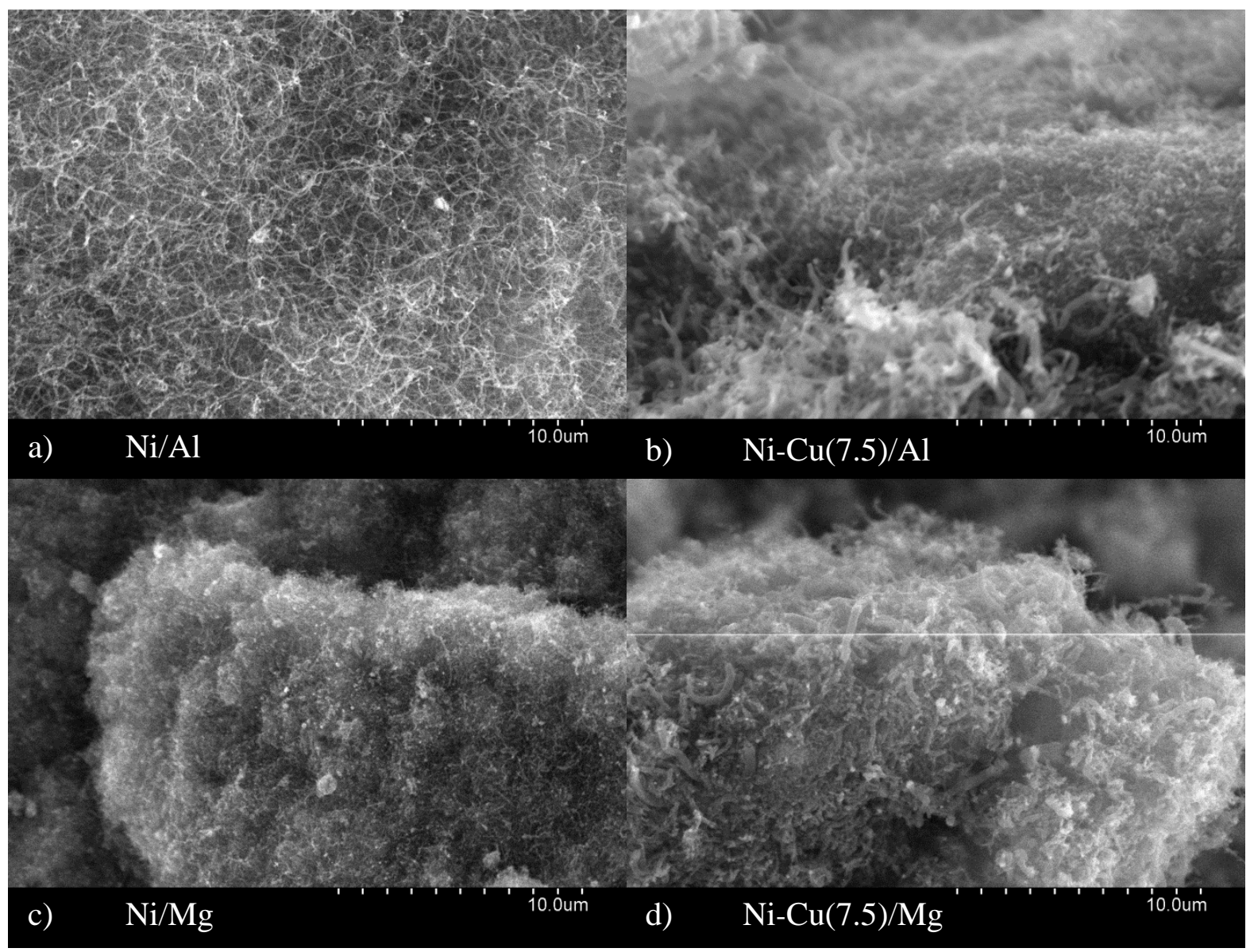

Fig. 9. SEM micrographs of the carbon nanofilaments obtained on a) $\mathrm{Ni} / \mathrm{Al}$; b) $\mathrm{Ni}-\mathrm{Cu}(7.5) / \mathrm{Al}$;

c) $\mathrm{Ni} / \mathrm{Mg}$; and d) $\mathrm{Ni}-\mathrm{Cu}(7.5) / \mathrm{Mg}$. 


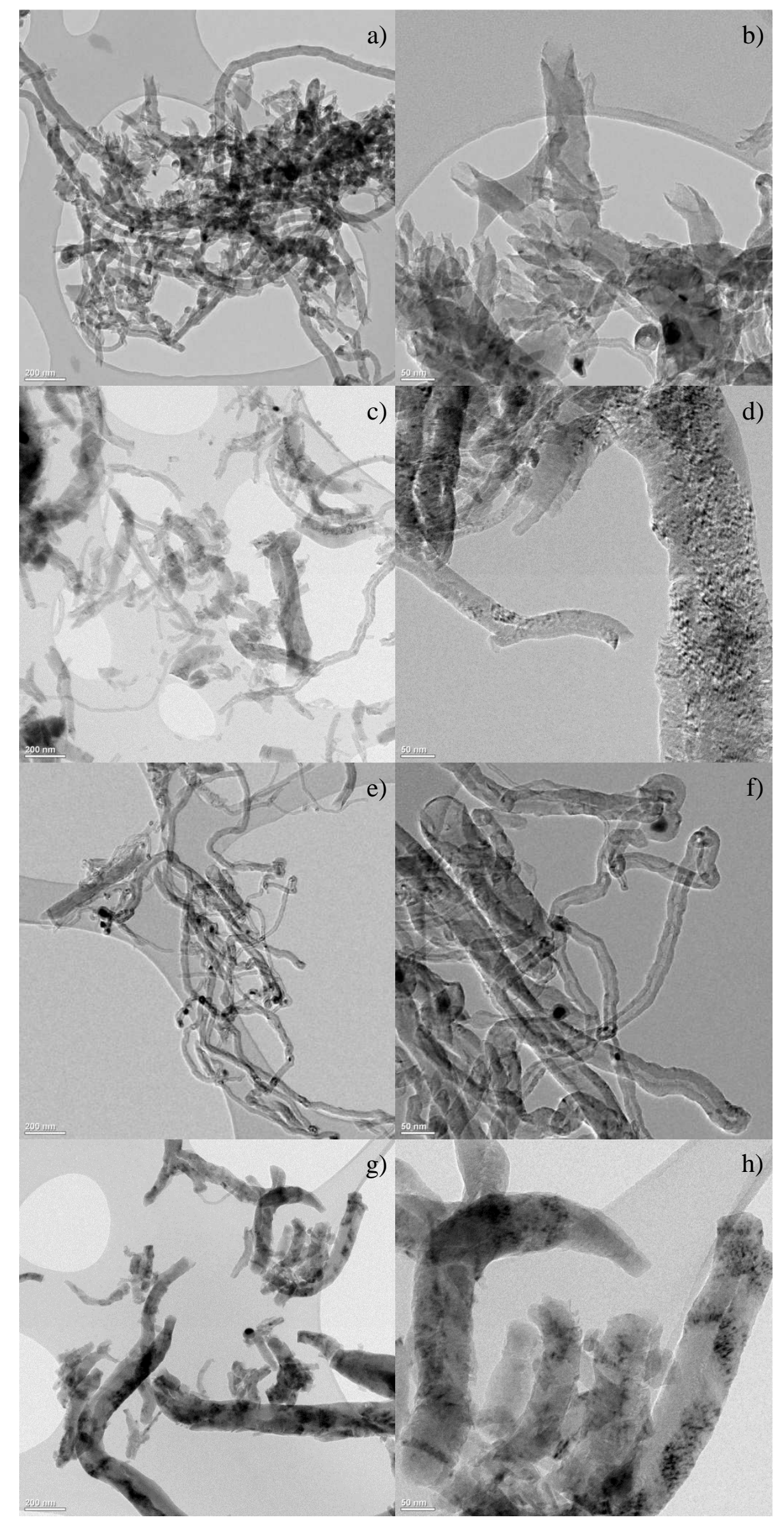


Fig. 10. TEM images of the carbon nanofilaments obtained on a-b) Ni/Al, c-d) Ni-Cu(7.5)/Al, e-f) $\mathrm{Ni} / \mathrm{Mg}$ and g-h) $\mathrm{Ni}-\mathrm{Cu}(7.5) / \mathrm{Mg}$.

\section{CONCLUSIONS}

Massive Ni- and Ni-Cu-based catalysts have been developed and their behavior in the CDM reaction for $\mathrm{H}_{2}$ and nanostructured carbon production has been studied. $\mathrm{Cu}$ doping enhanced the catalyst activity in terms of yield to $\mathrm{H}_{2}$ and carbon formation, as well as its lifetime and activity at higher operating temperatures.

- Temperature-programmed mode thermogravimetry was useful to establish quickly the optimal working temperature region of each catalyst in terms of catalytic activity. An optimal $\mathrm{Cu}$ content of $7.5 \mathrm{~mol} \%$ in the catalysts, independently of the textural promoter used, offered the best behavior in the CDM test.

- At Isothermal conditions, Cu-doped catalysts also showed higher carbon yields and longer times of activity at any operating temperature. Likewise, doped catalysts exhibited activity at temperatures at which undoped catalysts did not (above 700 and $600{ }^{\circ} \mathrm{C}$ for $\mathrm{Ni} / \mathrm{Al}$ and $\mathrm{Ni} / \mathrm{Mg}$, respectively). Higher operating temperatures in the $\mathrm{CDM}$ reaction allow achieving a greater methane conversion by solving the thermodynamic limitations imposed by low operating temperatures.

- The characterization of reduced catalysts and carbonaceous products obtained by CDM in a FBR revealed both the obtention of fishbone-type CNF and MWCNT, and the involvement of the catalyst crystalline structure in characteristics such as the $\alpha$ angle between the graphene stacks and the growth axis of the nanofilament, the diameter, the length and the formation or not of an inner hollow.

- $\mathrm{Cu}$ doping forms $\mathrm{Ni}_{(\mathrm{x})} \mathrm{Cu}_{(1-\mathrm{x})}$ alloys with a higher lattice constant favoring the carbon diffusion through the particle. It promotes an increase in the carbon formation rate as 
well in the formation of denser carbon nanofilaments (larger graphite crystallites and less interlayer spacing).

\section{Acknowledgments}

This work was funded by FEDER and the Spanish Economy and Competitiveness Ministry (MINECO) (ENE2011-28318-C03-01 and ENE2014-52189-C02-01-R). DT thanks for the award of his $\mathrm{PhD}$ under the frame of ENE2011-28318-C03-01 project. JLP thanks MINECO for his Ramon y Cajal research contract (RYC-2013-12494). The microscopy works have been conducted in the "Laboratorio de Microscopías Avanzadas" at "Instituto de Nanociencia de Aragón - Universidad de Zaragoza”. Authors acknowledge the LMA-INA for offering access to their instruments and expertise.

\section{References}

[1] N. Muradov, Hydrogen via methane decomposition: an application for decarbonization of fossil fuels, Int. J. Hydrogen Energy, 26 (2001) 1165-1175.

[2] N. Muradov, T. Vezirolu, From hydrocarbon to hydrogen-carbon to hydrogen economy, Int. J. Hydrogen Energy, 30 (2005) 225-237.

[3] H.F. Abbas, W.M.A. Wan Daud, Hydrogen production by methane decomposition: a review, Int. J. Hydrogen Energy, 35 (2010) 1160-1190.

[4] Y. Li, D. Li, G. Wang, Methane decomposition to COx-free hydrogen and nano-carbon material on group 810 base metal catalysts: a review, Catal. Today, 162 (2011) 1-48.

[5] H.a. Ichi-oka, N.o. Higashi, Y. Yamada, T. Miyake, T. Suzuki, Carbon nanotube and nanofiber syntheses by the decomposition of methane on group 8-10 metal-loaded MgO catalysts, Diamond Relat. Mater., 16 (2007) 1121-1125.

[6] A.M. Amin, E. Croiset, W. Epling, Review of methane catalytic cracking for hydrogen production, Int. J. Hydrogen Energy, 36 (2011) 2904-2935.

[7] I. Suelves, M. Lazaro, R. Moliner, B. Corbella, J. Palacios, Hydrogen production by thermo catalytic decomposition of methane on Ni-based catalysts: influence of operating conditions on catalyst deactivation and carbon characteristics, Int. J. Hydrogen Energy, 30 (2005) 1555-1567.

[8] L.B. Avdeeva, O.V. Goncharova, D.I. Kochubey, V.I. Zaikovskii, L.M. Plyasova, B.N. Novgorodov, S.K. Shaikhutdinov, Coprecipitated Ni-alumina and $\mathrm{Ni} \square \mathrm{Cu}$-alumina catalysts of methane decomposition and carbon deposition. II. Evolution of the catalysts in reaction, Appl. Catal. A, 141 (1996) 117-129.

[9] N.A. Hermes, M.A. Lansarin, O.W. Perez-Lopez, Catalytic Decomposition of Methane Over M-Co-Al Catalysts (M = Mg, Ni, Zn, Cu), Catal. Lett., 141 (2011) 1018-1025.

[10] G.D.B. Nuernberg, H.V. Fajardo, E.L. Foletto, S.M. Hickel-Probst, N.L.V. Carreño, L.F.D. Probst, J. Barrault, Methane conversion to hydrogen and nanotubes on Pt/Ni catalysts supported over spinel MgAl2O4, Catal. Today, 176 (2011) 465-469.

[11] W. Wang, H. Wang, Y. Yang, S. Jiang, Ni-SiO2 and Ni-Fe-SiO2 catalysts for methane decomposition to prepare hydrogen and carbon filaments, Int. J. Hydrogen Energy, 37 (2012) 9058-9066.

[12] A.E. Awadallah, A.A. Aboul-Enein, A.K. Aboul-Gheit, Various nickel doping in commercial Ni$\mathrm{Mo} / \mathrm{Al} 2 \mathrm{O} 3$ as catalysts for natural gas decomposition to COx-free hydrogen production, Renewable Energy, 57 (2013) 671-678. 
[13] S. Takenaka, Y. Shigeta, E. Tanabe, K. Otsuka, Methane decomposition into hydrogen and carbon nanofibers over supported Pd-Ni catalysts, J. Catal., 220 (2003) 468-477.

[14] G. Wang, Y. Jin, G. Liu, Y. Li, Production of Hydrogen and Nanocarbon from Catalytic Decomposition of Methane over a Ni-Fe/Al2O3 Catalyst, Energy Fuels, 27 (2013) 4448-4456.

[15] A.H. Fakeeha, W.U. Khan, A.S. Al-Fatesh, A.E. Abasaeed, M.A. Naeem, Production of hydrogen and carbon nanofibers from methane over Ni-Co-Al catalysts, Int. J. Hydrogen Energy, 40 (2015) 1774-1781.

[16] M. Pudukudy, Z. Yaakob, Z.S. Akmal, Direct decomposition of methane over SBA-15 supported Ni, Co and Fe based bimetallic catalysts, Appl. Surf. Sci., 330 (2015) 418-430.

[17] V.V. Chesnokov, V.I. Zaikovskii, R.A. Buyanov, V.V. Molchanov, L.M. Plyasova, Morphology of carbon from methane on nickel-containing catalysts, Catal. Today, 24 (1995) 265-267.

[18] H. Wang, R.T.K. Baker, Decomposition of Methane over a Ni-Cu-MgO Catalyst to Produce Hydrogen and Carbon Nanofibers, The Journal of Physical Chemistry B, 108 (2004) 20273-20277.

[19] I. Suelves, M.J. Lázaro, R. Moliner, Y. Echegoyen, J.M. Palacios, Characterization of NiAl and NiCuAl catalysts prepared by different methods for hydrogen production by thermo catalytic decomposition of methane, Catal. Today, 116 (2006) 271-280.

[20] Y. Echegoyen, I. Suelves, M.J. Lázaro, R. Moliner, J.M. Palacios, Hydrogen production by thermocatalytic decomposition of methane over $\mathrm{Ni}-\mathrm{Al}$ and $\mathrm{Ni}-\mathrm{Cu}-\mathrm{Al}$ catalysts: Effect of calcination temperature, J. Power Sources, 169 (2007) 150-157.

[21] M.J. Lázaro, Y. Echegoyen, I. Suelves, J.M. Palacios, R. Moliner, Decomposition of methane over Ni-SiO2 and Ni-Cu-SiO2 catalysts: Effect of catalyst preparation method, Appl. Catal. A, 329 (2007) 22-29.

[22] Y. Echegoyen, I. Suelves, M.J. Lázaro, M.L. Sanjuán, R. Moliner, Thermo catalytic decomposition of methane over $\mathrm{Ni}-\mathrm{Mg}$ and $\mathrm{Ni}-\mathrm{Cu}-\mathrm{Mg}$ catalysts: Effect of catalyst preparation method, Appl. Catal. A, 333 (2007) 229-237.

[23] A.C. Lua, H.Y. Wang, Decomposition of methane over unsupported porous nickel and alloy catalyst, Applied Catalysis B: Environmental, 132-133 (2013) 469-478.

[24] S.K. Saraswat, K.K. Pant, Synthesis of hydrogen and carbon nanotubes over copper promoted Ni/SiO2 catalyst by thermocatalytic decomposition of methane, Journal of Natural Gas Science and Engineering, 13 (2013) 52-59.

[25] I.A. Strel'tsov, O.B. Vinokurova, I.V. Tokareva, I.V. Mishakov, V.P. Isupov, Y.V. Shubin, A.A. Vedyagin, Effect of the nature of a textural promoter on the catalytic properties of a nickel-copper catalyst for hydrocarbon processing in the production of carbon nanofibers, Catalysis in Industry, 6 (2014) 176-181.

[26] I.A. Strel'tsov, I.V. Mishakov, I.V. Tokareva, K.S. Golohvast, A.A. Vedyagin, D.V. Korneev, Prospects for the use of ultrasonic spray pyrolysis to prepare catalysts for the synthesis of carbon nanofibers, Nanotechnologies in Russia, 9 (2014) 715-722.

[27] Y. Shen, A.C. Lua, Synthesis of Ni and Ni-Cu supported on carbon nanotubes for hydrogen and carbon production by catalytic decomposition of methane, Applied Catalysis B: Environmental, 164 (2015) 61-69.

[28] G. Naresh, V. Vijay Kumar, C. Anjaneyulu, J. Tardio, S.K. Bhargava, J. Patel, A. Venugopal, Nano size H $\beta$ zeolite as an effective support for $\mathrm{Ni}$ and $\mathrm{NiCu}$ for $\mathrm{COx}$ free hydrogen production by catalytic decomposition of methane, Int. J. Hydrogen Energy, 41 (2016) 19855-19862.

[29] F.M. Berndt, O.W. Perez-Lopez, Catalytic decomposition of methane over Ni/SiO2: influence of $\mathrm{Cu}$ addition, Reaction Kinetics, Mechanisms and Catalysis, 120 (2017) 181-193.

[30] N. Bayat, M. Rezaei, F. Meshkani, Methane dissociation to COx-free hydrogen and carbon nanofiber over Ni-Cu/Al2O3 catalysts, Fuel, 195 (2017) 88-96.

[31] N. Gutta, V.K. Velisoju, A. Chatla, V. Boosa, J. Tardio, J. Patel, V. Akula, Promotional Effect of Cu and Influence of Surface Ni-Cu Alloy for Enhanced H2 Yields from CH4 Decomposition over Cu-Modified Ni Supported on MCM-41 Catalyst, Energy Fuels, 32 (2018) 4008-4015.

[32] J. Ashok, S.N. Kumar, A. Venugopal, V.D. Kumari, S. Tripathi, M. Subrahmanyam, COx free hydrogen by methane decomposition over activated carbons, Catal. Commun., 9 (2008) 164-169.

[33] J. Ashok, S.N. Kumar, M. Subrahmanyam, A. Venugopal, Pure H2 Production by Decomposition of Methane Over Ni Supported on Hydroxyapatite Catalysts, Catal. Lett., 121 (2008) 283-290.

[34] Á. Calafat, N. Sánchez, Production of carbon nanotubes through combination of catalyst reduction and methane decomposition over $\mathrm{Fe}-\mathrm{Ni} / \mathrm{ZrO} 2$ catalysts prepared by the citrate method, Appl. Catal. A, 528 (2016) 14-23.

[35] S. Takenaka, H. Ogihara, I. Yamanaka, K. Otsuka, Decomposition of methane over supported-Ni catalysts: effects of the supports on the catalytic lifetime, Appl. Catal. A, 217 (2001) 101-110.

[36] J. Majewska, B. Michalkiewicz, Carbon nanomaterials produced by the catalytic decomposition of methane over Ni/ZSM-5: Significance of Ni content and temperature, New Carbon Materials, 29 (2014) 102-108.

[37] J.-H. Park, J.-H. Choung, I.-S. Nam, S.-W. Ham, N2O decomposition over wet- and solid-exchanged FeZSM-5 catalysts, Applied Catalysis B: Environmental, 78 (2008) 342-354. 
[38] C. Tanggarnjanavalukul, W. Donphai, T. Witoon, M. Chareonpanich, J. Limtrakul, Deactivation of nickel catalysts in methane cracking reaction: Effect of bimodal meso-macropore structure of silica support, Chem. Eng. J. (Lausanne), 262 (2015) 364-371.

[39] N. Bayat, M. Rezaei, F. Meshkani, Methane decomposition over Ni-Fe/A12O3 catalysts for production of COx-free hydrogen and carbon nanofiber, Int. J. Hydrogen Energy, 41 (2016) 1574-1584.

[40] A.R. Naghash, Z. Xu, T.H. Etsell, Coprecipitation of Nickel-Copper-Aluminum Takovite as Catalyst Precursors for Simultaneous Production of Carbon Nanofibers and Hydrogen, Chem. Mater., 17 (2005) 815-821. [41] A. Hornés, P. Bera, M. Fernández-García, A. Guerrero-Ruiz, A. Martínez-Arias, Catalytic and redox properties of bimetallic $\mathrm{Cu}-\mathrm{Ni}$ systems combined with $\mathrm{CeO} 2$ or $\mathrm{Gd}$-doped $\mathrm{CeO} 2$ for methane oxidation and decomposition, Applied Catalysis B: Environmental, 111-112 (2012) 96-105.

[42] W.J. Jong, S.H. Lai, K.H. Hong, H.N. Lin, H.C. Shih, The effect of catalysis on the formation of onedimensional carbon structured materials, Diamond Relat. Mater., 11 (2002) 1019-1025.

[43] R.T. Yang, J.P. Chen, Mechanism of carbon filament growth on metal catalysts, J. Catal., 115 (1989) 52-64.

[44] D. Torres, J.L. Pinilla, M.J. Lázaro, R. Moliner, I. Suelves, Hydrogen and multiwall carbon nanotubes production by catalytic decomposition of methane: thermogravimetric analysis and scaling-up of $\mathrm{Fe}-\mathrm{Mo}$ catalysts, Int. J. Hydrogen Energy, 39 (2014) 3698-3709.

[45] N. Latorre, F. Cazaña, V. Martínez-Hansen, C. Royo, E. Romeo, A. Monzón, Ni-Co-Mg-Al catalysts for hydrogen and carbonaceous nanomaterials production by CCVD of methane, Catal. Today, 172 (2011) 143-151.

[46] R. Guil-Lopez, J.A. Botas, J.L.G. Fierro, D.P. Serrano, Comparison of metal and carbon catalysts for hydrogen production by methane decomposition, Appl. Catal. A, 396 (2011) 40-51.

[47] J.L. Pinilla, I. Suelves, M.J. Lázaro, R. Moliner, J.M. Palacios, Activity of NiCuAl catalyst in methane decomposition studied using a thermobalance and the structural changes in the $\mathrm{Ni}$ and the deposited carbon, Int. J. Hydrogen Energy, 33 (2008) 2515-2524.

[48] J. Biscoe, An X-ray study of carbon black, J. Appl. Phys., 13 (1942) 364-371.

[49] J.I. Villacampa, C. Royo, E. Romeo, J.A. Montoya, P. Del Angel, A. Monzón, Catalytic decomposition of methane over Ni-A12O3 coprecipitated catalysts: Reaction and regeneration studies, Appl. Catal. A, 252 (2003) 363-383.

[50] J.L. Pinilla, I. Suelves, M.J. Lázaro, R. Moliner, J.M. Palacios, Influence of nickel crystal domain size on the behaviour of $\mathrm{Ni}$ and $\mathrm{NiCu}$ catalysts for the methane decomposition reaction, Appl. Catal. A, 363 (2009) 199207.

[51] T.V. Reshetenko, L.B. Avdeeva, Z.R. Ismagilov, A.L. Chuvilin, V.A. Ushakov, Carbon capacious Ni-CuAl2O3 catalysts for high-temperature methane decomposition, Appl. Catal. A, 247 (2003) 51-63.

[52] C. Li, Y.-W. Chen, Temperature-programmed-reduction studies of nickel oxide/alumina catalysts: effects of the preparation method, Thermochim. Acta, 256 (1995) 457-465.

[53] I.-K. Suh, H. Ohta, Y. Waseda, High-temperature thermal expansion of six metallic elements measured by dilatation method and X-ray diffraction, J. Mater. Sci., 23 (1988) 757-760.

[54] L. Thomassen, An X-Ray Investigation of the System Cr2O3-NiO1, J. Am. Chem. Soc., 62 (1940) 11341136.

[55] R.M. Hazen, Effects of temperature and pressure on the cell dimension and X-ray temperature factors of periclase, Am. Mineral., 61 (1976) 266-271.

[56] A.R. Denton, N.W. Ashcroft, Vegard's law, Phys. Rev. A, 43 (1991) 3161-3164.

[57] H. Cui, X. Wu, Y. Chen, J. Zhang, R.I. Boughton, Influence of copper doping on chlorine adsorption and antibacterial behavior of MgO prepared by co-precipitation method, Mater. Res. Bull., 61 (2015) 511-518.

[58] R. Alizadeh, E. Jamshidi, H. Ale Ebrahim, Kinetic Study of Nickel Oxide Reduction by Methane, Chem. Eng. Technol., 30 (2007) 1123-1128.

[59] I.V. Mishakov, Y.I. Bauman, I.A. Streltsov, D.V. Korneev, O.B. Vinokurova, A.A. Vedyagin, The regularities of the formation of carbon nanostructures from hydrocarbons based on the composition of the reaction mixture, Resource-Efficient Technologies, 2 (2016) 61-67.

[60] N.M. Rodriguez, M.S. Kim, R.T.K. Baker, Deactivation of Copper Nickel-Catalysts Due to Changes in Surface Composition, J. Catal., 140 (1993) 16-29.

[61] A. Peigney, C. Laurent, E. Flahaut, R.R. Bacsa, A. Rousset, Specific surface area of carbon nanotubes and bundles of carbon nanotubes, Carbon, 39 (2001) 507-514.

[62] D. Torres, J.L. Pinilla, I. Suelves, Unzipping of multi-wall carbon nanotubes with different diameter distributions: Effect on few-layer graphene oxide obtention, Appl. Surf. Sci., 424 (2017) 101-110.

[63] P. Trucano, R. Chen, Structure of graphite by neutron diffraction, Nature, 258 (1975) 136.

[64] Y.-A. Zhu, Y.-C. Dai, D. Chen, W.-K. Yuan, First-principles study of carbon diffusion in bulk nickel during the growth of fishbone-type carbon nanofibers, Carbon, 45 (2007) 21-27.

[65] J.W. Snoeck, G.F. Froment, M. Fowles, Filamentous carbon formation and gasification: Thermodynamics, driving force, nucleation, and steady-state growth, J. Catal., 169 (1997) 240-249. 
[66] S. Hofmann, G. Csányi, A.C. Ferrari, M.C. Payne, J. Robertson, Surface diffusion: The low activation energy path for nanotube growth, Phys. Rev. Lett., 95 (2005). 
- A thermogravimetric-based catalysts screening in the catalytic methane reaction decomposition is presented.

- The effect of $\mathrm{Cu}$ doping in $\mathrm{Ni} / \mathrm{MgO}$ and $\mathrm{Ni} / \mathrm{Al}_{2} \mathrm{O}_{3}$ catalysts on their catalytic stability and activity in the CDM is studied.

- $\mathrm{Cu}$ doping resulted in higher carbon yields and longer times of activity with an optimal $\mathrm{Cu}$ content of 7.5 molar \%

- $\mathrm{Cu}$ doping promotes the obtention of fishbone-type CNF instead CNT

- $\mathrm{Ni}_{(\mathrm{x})} \mathrm{Cu}_{(1-\mathrm{x})}$ alloys with a higher lattice constant favor carbon bulk diffusion and an increase in carbon formation rate. 

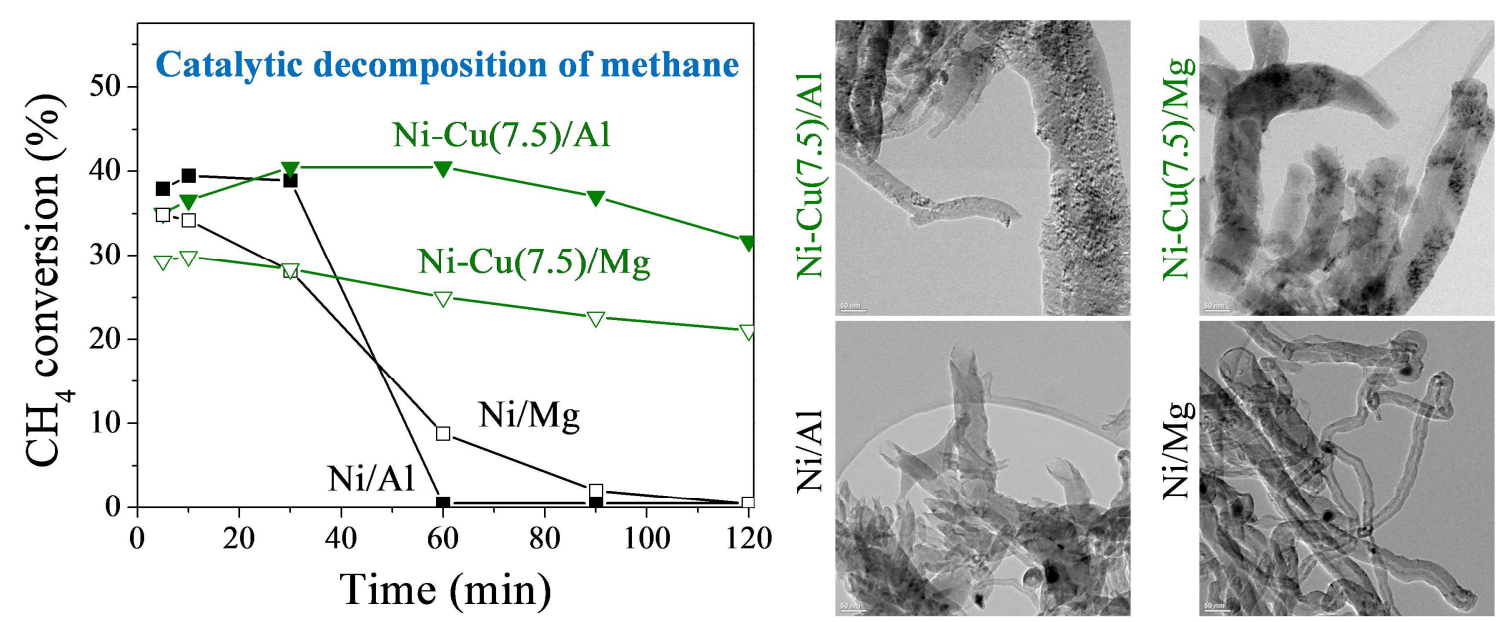